Journal of the Scientific Agricultural Society of Finland Vol. 53: 341-390, 1981

Maataloustieteellinen Aikakauskirja

\title{
THE INTERACTION OF MICROORGANISMS AND THE HERBICIDES CHLORTHIAMID AND DICHLOBENIL
}

Selostus: Mikrobien sekä herbisidien klortiamidin ja diklobeniilin keskinäiset vaikutukset.

\section{HELVI HEINONEN-TANSKI}

Department of Microbiology

University of Helsinki

SF-00710 Helsinki 71

Finland

ACADEMIC DISSERTATION

To be presented, with the permission of the Faculty of Agriculture and Forestry of the University of Helsinki, for public criticism in Auditorium XII on March 12, 1982:0 at 12 o'clock.

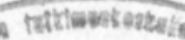

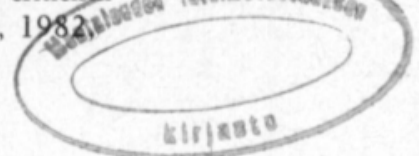


ISBN 951-9041-17-6

ISSN 0024-8835 


\section{Preface}

The present investigation was carried out at the Department of Microbiology, University of Helsinki with the supporting of the Academy of Finland between the years 1973-1980.

I would like to thank Professor Helge Gyllenberg and Professor Seppo Niemelä, the acting heads of the department for the support they have given me during my research work.

My special thanks are due to Docent Eva Eklund, $\mathrm{Ph}$. D. and Docent Marja-Liisa Hattula, Ph. D. for reading of the manuscript with valuable and constructive criticism.

I am also grateful to Mrs. Sisko Kilpi, Lic. Ph. and Mrs. Zlata Klokoćar Smit, M. Sc. and Mr. Antti UusiRauva, M. Sc. for many discussions.

My sincere thanks are due to Mrs. Kristina Lindström, M. Sc. for the cowork about metabolism and cometabolism and Mrs. Aila Mettälä, M. Sc., Mrs. Liisa Aunula, Mrs. Eva Nyreen and Mr. Robert Harper, M. Sc. for laboratory work.

The English text is corrected by Mr. Michael Bailey, B. Sc. and the drawings are made by Miss Raija Tuomela.

I also thank Philips-Duphar and Shell Ltd and Professor H.-J. Knackmuss for the chemicals commercially unavailable.

Finally, I wish to extend my thanks to the Scientific Agricultural Society of Finland for including my dissertation in this journal and the Finnish Cultural Foundation for the grant to my research work.

Helsinki December 1981

Helvi Heinonen-Tanski 



\section{CONTENTS}

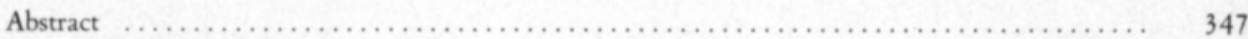

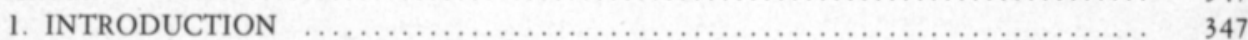

1.1. The herbicides chlorthiamid and dichlobenil $\ldots \ldots \ldots \ldots \ldots \ldots \ldots \ldots \ldots \ldots \ldots \ldots . \ldots \ldots$

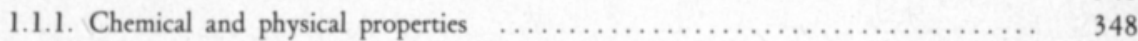

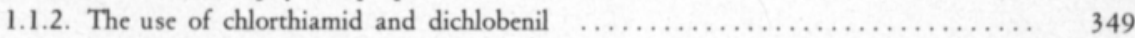

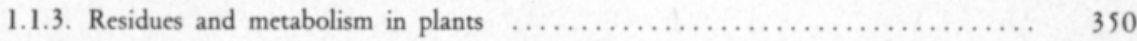

1.1.4. The mode of action of chlorthiamid and dichlobenil $\ldots \ldots \ldots \ldots \ldots \ldots \ldots . \ldots \ldots$

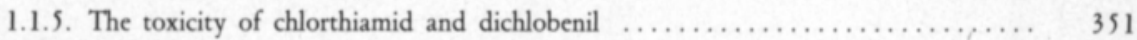

2. THE EFFECTS OF CHLORTHIAMID AND DICHLOBENIL ON

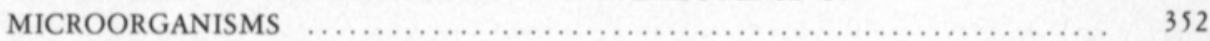

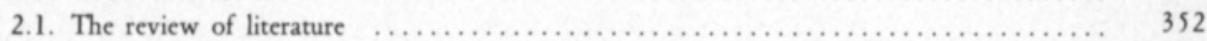

2.2. The methods for studying the effects of herbicides on microorganisms $\ldots \ldots \ldots \ldots \ldots .353$

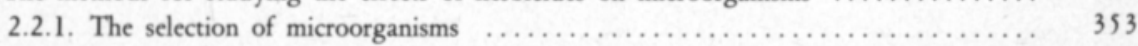

2.2.2. The methods for studying the effects of herbicides on the growth of the

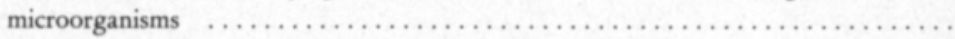

2.2.3. The methods for studying actinomycete ATPase activities ............... 355

2.3. Observed effects of dichlobenil and chlorthiamid on microorganisms ........... 355

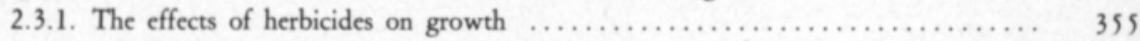

2.3.2. The effects of dichlobenil on ATPase activities $\ldots \ldots \ldots \ldots \ldots \ldots \ldots \ldots \ldots \ldots$

2.4. Discussion of the effects of herbicides on microorganisms $\ldots \ldots \ldots \ldots \ldots \ldots \ldots \ldots \ldots . \ldots \ldots$

3. THE EFFECTS OF MICROORGANISMS ON THE HERBICIDES CHLORTHIAMID

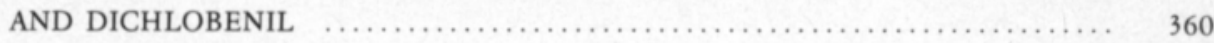

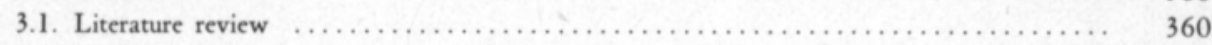

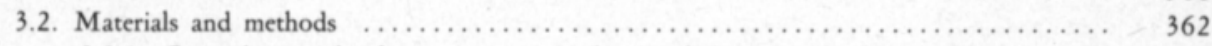

3.2.1. General principles for investigations of cometabolic pesticide degradation capacity by

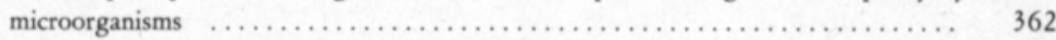

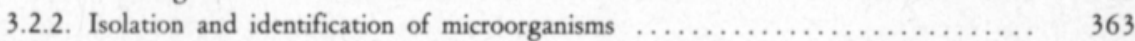

3.2.3. Investigations of metabolism and cometabolism of 2,6-dichlorobenzoic acid derivatives 364

3.2.4. Degradation of. the herbicides, chlorthiamid. and. dichlobenil ............ 365

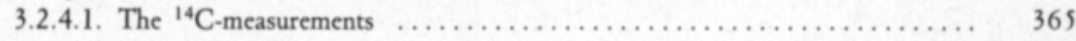

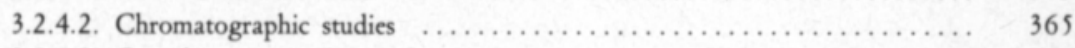

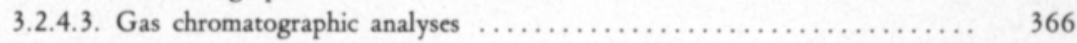

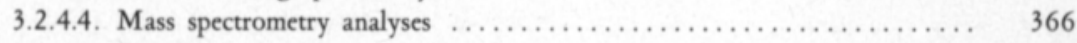

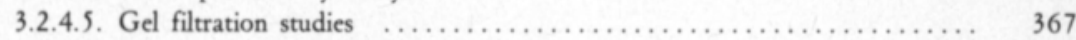

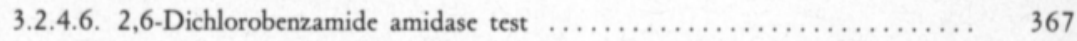

3.2.4.7. Dechlorination test for dichlobenil and some related compounds ...... 367

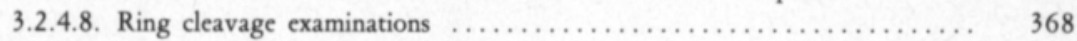

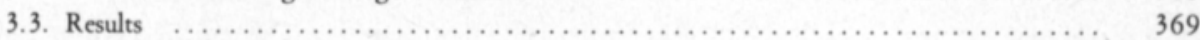

3.3.1. Characterization of microorganisms isolated ...................... 369

3.3.2. Degradation of 2,6-dichlorobenzoic acid compounds $\ldots \ldots \ldots \ldots \ldots \ldots \ldots \ldots$

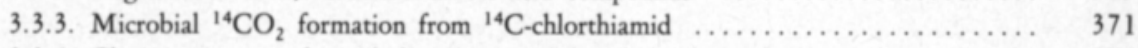

3.3.4. Characterization of metabolites separated by chromatography $\ldots \ldots \ldots \ldots \ldots .372$

3.3.5. Ability of microorganisms to produce ammonia from 2,6-dichlorobenzamide ... 377

3.3.6. The dechlorination of dichlobenil and related compounds $\ldots \ldots \ldots \ldots \ldots \ldots . \ldots \ldots 77$

3.3.7. Cleavage of the aromatic ring of benzamide derivatives $\ldots \ldots \ldots \ldots \ldots \ldots \ldots$

3.4. Discussion of the degradation of chlorthiamid and dichlobenil . . . . . . . . . . . . 379

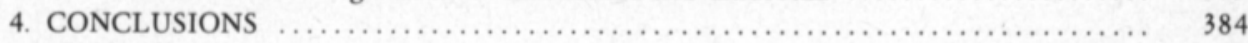

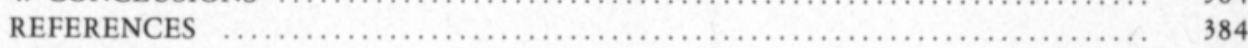

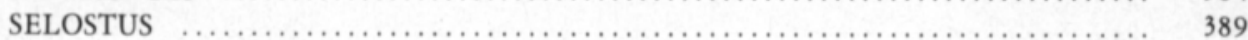





\title{
HEINONEN-TANSKI, H. 1981. The interaction of microorganisms and the herbicides chlorthiamid and dichlobenil.
}

\author{
J. Scient. Agric. Soc. Finl. 53: 341-390
}

\begin{abstract}
The herbicides chlorthiamid and dichlobenil inhibited the growth of some actinomycetes in starch-casein medium. The effect of these herbicides on the other bacteria tested was insignificant.

Chlorthiamid and dichlobenil are slowly degradable herbicides. Bacteria such as Artbrobacter, unidentified coryneforms and Bacillus could degrade the herbicides by cometabolism. 2,6-Dichlorobenzamide, 2,6-dichlorobenzoic acid, carbon dioxide, chloride, a catechol compound and many unidentified compounds were found as metabolites. Artbrobacter strains capable for dechlorination could also cleave the aromatic ring, both processes occurring in aerated cultures. More than half of the chloride was liberated in three weeks at $28^{\circ} \mathrm{C}$ by the most active Artbrobacter strain.
\end{abstract}

\section{Introduction}

The major goal of human agricultural and silvicultural activity has always been to obtain high yields and man has always studied ways of growing his crops economically and easily.

Weeds have always been one factor reducing yields very significantly. Traditionally, all the members of rural people spent large amounts of time weeding in order to save as much of crop yields as possible.

Modern herbicides have proved to be a good weapon against weeds. Without herbicides intensive, mechanized agriculture would hardly be possible, as modern combines could not cope with weed-infected cereals. In horticulture it is also cheaper to use herbicides than human labour for weed control.

Underbrush and grass weeds were traditionally controlled by cattle tended by a shepherd. Later, control was carried out by a man with a brush hook. Instead of these the control can nowadays be effected by herbicides spread either from an aeroplane or a tractor or else using manual spraying.

When using synthetic herbicides their weed control efficiency must of cource be known. In addition, their possible environmental effects must also be taken into account. In particular, their effects on soil microflora should be considered because any changes in the microflora may have important effects on soil fertility. 
In agricultural practice it is very important to know how long herbicides persist in soil and whether it is possible to influence their degradation rate. The persistence of herbicides must be sufficiently long to kill the weeds, but the residues must be in such low concentrations that crops will not be affected.

The work here described was carried out with the aim of providing some answers to these questions.

The herbicides chlorthiamid and dichlobenil were selected as the objects of this study because although they were known to leave residues in soil, they are so new as herbicides that their degradation pathways and their effects on microorganisms is largely unknown. MUKULA (1973) assumed that they will be used for a considerable time into the future.

These herbicides have now been used for some years in Finland, in a small but increasing scale. In 1973 a total of 14 tons of active chlorthiamid and some related compounds were used (MARKKULA 1974). By 1975 the use of these chemicals reached its maximum of 20 tons (TIITTANEN and BLOMQVIST 1976). According to the latest statistical data (TIITTANEN and BLOMQVIST 1980) 18.6 tons of herbicides containing chlorthiamid and related compounds were sold in Finland in 1979.

\subsection{The herbicides chlorthiamid and dichlobenil}

\subsubsection{Chemical and physical properties}

Chlorthiamid (2,6-dichlorothiobenzamide) is at room temperature a white crystalline substance. Its melting point is $152^{\circ} \mathrm{C}$ and its vapour pressure at $20^{\circ} \mathrm{C}$ is $1.3 \times 10^{-4} \mathrm{~Pa}$. Its solubility in water at $21^{\circ} \mathrm{C}$ is $950 \mathrm{mg} / \mathrm{kg}$ (MARTIN 1971). The molecular weight is 206 .

Chlorthiamid degrades chemically very easily to dichlobenil (2,6-dichlorophenyl cyanide or 2,6-dichlorobenzonitrile). RAJASEKHARAN PILLAI (1977) has proposed persulphonic acid of 2,6-dichlorophenyl cyanide to be an intermediate product in the photochemical degradation of chlorthiamid to dichlobenil in the presence of a photosensitizer (dye, riboflavin etc.).

Dichlobenil is also a white crystalline substance at room temperature. Its molecular weight is 174 and its melting point $145-147^{\circ} \mathrm{C}$. The vapour pressure is $7.3 \times 10^{-2} \mathrm{~Pa}$ at $20^{\circ} \mathrm{C}$ and only $2.1 \mathrm{~Pa}$ at $50^{\circ} \mathrm{C}$, indicating that dichlobenil is very volatile. Because of its volatility this chemical should not be used or stored in greenhouses or in the same storage room as living plant matter. The solubility of dichlobenil is only $18 \mathrm{mg} / \mathrm{kg}$ in water at $20^{\circ} \mathrm{C}$ (MARTIN 1971). The very low solubility of dichlobenil is a useful property: dichlobenil remains almost completely in the place where it has been applied and does not move with water. However, although dichlobenil dissolves only very slightly it may on the other hand codistillate quite easily with water.

Dichlobenil dissolves in and is adsorbed to organic solvents very well. The fraction coefficient between organic and aqueous phases is with lignin 400-1,000 and with highly organic soil 180 (MASSINI 1961). Thus the concentration of dichlobenil may be much higher in soils rich in organic matter than in pure water.

Chemically dichlobenil is rather stable. In UV light it produces 2-chlorobenzonitrile and benzonitrile (PLIMMER and HUMMER 1968). The reaction proceeds well in methanol and may also be important in nature. 
Fig. 1. UV-light dechlorinates dichlobenil to 2-chlorobenzonitrile and benzonitrile (PLIMMER and HUMMER 1968).

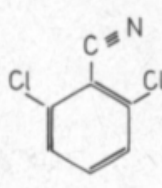

dichlobenil

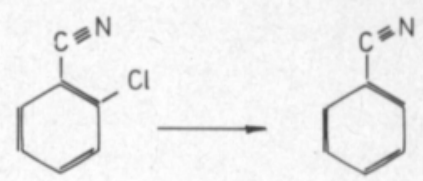

2 -chlorobenzonitrile

benzonitrile

Dichlobenil can be chemically hydrolyzed to 2,6-dichlorobenzamide by alkaline hydrolysis (GRIFFITHS et al. 1966) or acidic hydrolysis (BRIGGS and DAWSON 1970).

\subsubsection{The use of cblortbiamid and dicblobenil}

Chlorthiamid was introduced as a herbicide in 1963 by Shell Limited, London and dichlobenil in 1960 N. V. Philips-Duphar, Amsterdam. Both of these compounds are soil-acting herbicides used mainly to control germinating annual weeds (MARTIN 1971).

Chlorthiamid has been imported to Finland since 1967 by Kemira Oy, Helsinki. The only formulation is a granular powder sold under the name Rikkaruohontuho Prefix. It contains $75 \mathrm{~g}$ chlorthiamid in $1 \mathrm{~kg}$ of the formulation (ANON. 1979 b).

In Finland there are at present two herbicide formulations available containing dichlobenil. A granular powder with the trade name Casoron $\mathrm{G}$ has been imported since 1971 by Berner Oy, Helsinki. It contains $67.5 \mathrm{~g}$ of dichlobenil in $1 \mathrm{~kg}$ of Casoron G (ANON. 1979 a). The other dichlobenil formulation used in Finland is Silvex Metsän Rikkaruohontuho imported by Kemira Oy, Helsinki. This formulation contains $15 \mathrm{~g}$ of dichlobenil and $15 \mathrm{~g}$ of atrazine per $\mathrm{kg}$.

The use of the formulations Rikkaruohotuho Prefix and Casoron $G$ is very similar. Both are recommended for weed control in the cultivation of apple trees, currents, gooseberries, raspberries and woody ornamentals both in nurseries and also during later stages of cultivation (ANON $1979 \mathrm{a}, \mathrm{b}$ ). Because of the granular form each tree or bush can be treated separately. Both of the herbicides can also be used as total herbicides in uncultivated areas such as garden paths, sports fields and railway areas. Dichlobenil has also been used against water weeds, but not in Finland (MARTIN 1971, HILTUNEN et al. 1979).

Silvex Metsän Rikkaruohontuho has been used in Finnish forests since 1968, particularly for killing weeds in new forests planted on former agricultural land (RUMMUKAINEN 1972). Silvex is also used extensively in forest nurseries.

Chlorthiamid and dichlobenil provide good control against many harmful weeds in Finland (RUMMUKAINEN 1972, KARHINIEMI 1977). In Swedish trials dichlobenil has proved to be very effective in connection with the cultivation of woody shrubs (SVENSSON 1976).

In the case of coniferous trees it has been found that the bark may be damaged if dichlobenil is spread too close to the trunks of young trees (WILKINSON and DAVIES 1970, RUMMUKAINEN 1974, OLBERG 1976). The treatment must therefore be carried out carefully, avoiding too high concentrations very close to seedlings, and in particular direct contact between the herbicide and the plant trunk. A mechanical granular spreader developed in the Finnish Forest Research Institute can be used in this work (RUMMUKAINEN 1974). 


\subsubsection{Residues and metabolism in plants}

The concentrations of residues of chlorthiamid and dichlobenil in growing plants are very low if the herbicides have been used according to the instructions. The highest concentration observed in a study of different crops treated in several Central and Southern European countries with varying amounts of chlorthiamid and dichlobenil formulations was $0.05 \mathrm{mg} / \mathrm{kg}$ (BEYNON et al. $1966 \mathrm{a}$ ). The levels administered included some high overdoses. In the Finnish tests the residues of chlorthiamid and dichlobenil in berries and apples were still lower, near to the detection limit $0.01 \mathrm{mg} / \mathrm{kg}$ (SILTANEN and VALTA $1972 \mathrm{a}, \mathrm{b}$, SILTANEN and ROSENBERG 1974).

Chlorthiamid (1) degrades completely to dichlobenil (2). Dichlobenil (2) in turn degrades either to 2,6-dichlorobenzamide (3), to 2,6-dichloro-3-hydroxybenzonitrile (4) or to 2,6-dichloro-4-hydroxybenzonitrile (5). In apple tree leaves hydroxybenzonitriles react with glycosides to form glycosides of 2,6-dichloro-3-hydroxybenzonitrile (8) and of 2,6-dichloro-4-hydroxybenzonitrile (9), but in wheat and rice leaves and stalks dichlobenil (2) metabolizes to 2,6-dichlorobenzamide (3) and to 2,6-dichloro-3-hydroxybenzamide (7) (BEYNON and WRIGHT 1968 b). VERLOOP and NIMMO (1969) found the same metabolic products in bean. However, SIKKA et al (1974) found 2,6-dichlorobenzoic acid (6) in parrot feather. All these reactions are shown in Fig. 2, which is based mainly on the work of VERLOOP and NIMMO (1969).<smiles>NCC1C(Cl)CCCC1Cl</smiles>

(1)

(2)

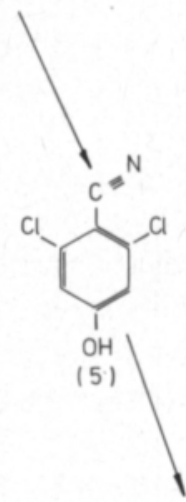<smiles>O=C1CCC2CCCC1C2Cl</smiles>

(6)

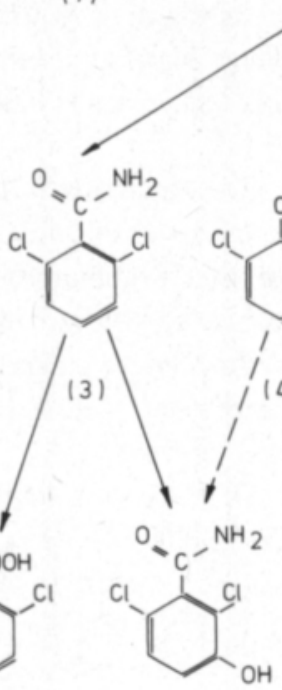

(7)<smiles>COC1CCC(Cl)C(CN)C1Cl</smiles>

(8)<smiles>COC1CC(Cl)C(CN)C(I)C1</smiles>

Fig. 2. The metabolism of chlorthiamid and dichlobenil in plants. 


\subsubsection{The mode of action of chlortbiamid and dicblobenil}

It is rather difficult to study the mode of action of chlorthiamid and dichlobenil, because many plants can metabolize these herbicides to different compounds which also have phytotoxic properties.

Some plant species, such as garden cress (Lepidium sativum), do not degrade dichlobenil. In these species dichlobenil swells the root tips and epidermis cells as well as the zone of elongation of the roots (VERLOOP 1972). Lignin formation increases but the calcium pectate content of cell walls is reduced. HOGETSU et al. (1974) found dichlobenil to inhibit cellulose synthesis in Vicia angularis.

In some other plant species the roots absorb dichlobenil, which then metabolizes by the mechanism presented in Fig. 2. 2,6-Dichlorobenzamide has been found to be phytotoxic, causing leaf margin chlorosis (BEYNON and WRIGHT $1968 \mathrm{~b}$, VERLOOP 1972). Furthermore 2,6-dichloro-3-hydroxybenzonitrile and 2,6-dichloro4-hydroxybenzonitrile have also been found to be phytotoxic (VERLOOP and NIMMO 1969). These compounds can inhibit phosphorylation in mitochondria of mung bean (Phaseolus aureus Roxb.) (MORELAND et al. 1974) and of rat liver (WIT and van GENDEREN 1966).

\subsubsection{The toxicity of chlorthiamid and dicblobenil}

The Finnish Plant Protection Institute publishes an official list of pesticides, which are divided into three categories. The first category contains poisonous pesticides with an $\mathrm{LD}_{s_{0}}$ value of less than $100 \mathrm{mg} / \mathrm{kg}$. Less poisonous pesticides with $\mathrm{LD}_{s_{0}}$ values between 100 and $3,000 \mathrm{mg} / \mathrm{kg}$ form the second category, while the third category is composed of pesticides with $\mathrm{LD}_{s_{0}}$ values of over $3,000 \mathrm{mg} / \mathrm{kg}$. The $\mathrm{LD}_{s_{0}}$ values presented are mainly determinated for the rat. In some cases a pesticide may be assigned to the first or second category despite high $\mathrm{LD}_{s_{0}}$ values (HILTUNEN et al. 1979).

The acute $\mathrm{LD}_{50}$ value of pure chlorthiamid is $757 \mathrm{mg} / \mathrm{kg}$ for rats, while that of dichlobenil is $3,160 \mathrm{mg} / \mathrm{kg}$ (MARTIN 1971).

However, dichlobenil has been found to cause chloracne in human skin (DEEKEN 1974). All the six cases reported occurred in association with the manufacture of herbicides. The patients had all been involved with the mixing or packaging of dichlobenil. In all cases the exposure had continued for weeks or months.

The no-effect level of dichlobenil for rat liver enzymes is $100-200 \mathrm{mg} / \mathrm{kg}$ (den TONKELAAR and van ESCH 1974).

GRIFFITHS et al. (1966) have studied the metabolism of chlorthiamid and dichlobenil in rats and dogs. They administered herbicides orally to the animals at levels of approximately $0.5-7 \mathrm{mg} / \mathrm{kg}$ and monitored excretion in the urine and faeces. Almost all the chlorthiamid and dichlobenil was excreted, mainly in the urine. In the rats the excretion took place in only one day, while in the dog $2-3$ days were required. 2,6-Dichloro-3-hydroxybenzonitrile was the main metabolite in rat urine. The amounts of 2,6-dichlorobenzamide and 2,6-dichlorobenzoic acid were low. The metabolic route is presented in Fig. 3. Most metabolic products seem to be the same as in plants.

Dichlobenil is rather toxic to fish (COPE et al. 1969, BOLIER et al. 1973, WIERSMA-ROEM et al. 1978), which is of importance if dichlobenil is used in water. Even doses of less than $10 \mathrm{mg} / \mathrm{kg}$ seem to be very toxic. 


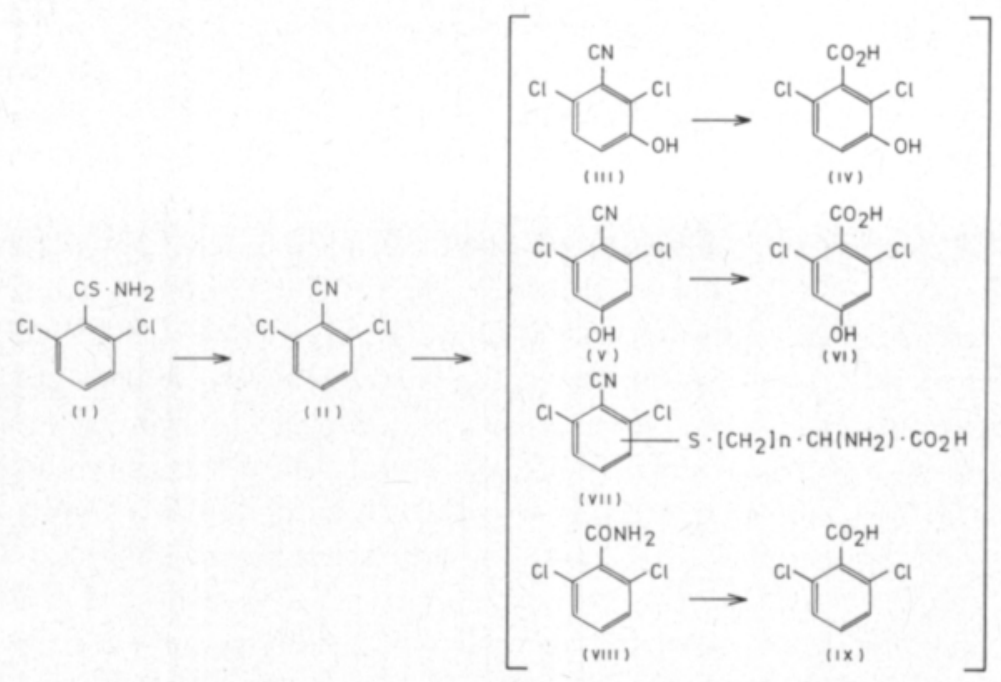

Fig. 3. The metabolism of chlorthiamid in the rat (GRIFFITHS et al. 1966, republished with the author' permission). I = chlorthiamid, II = dichlobenil, III $=2,6$-dichloro-3-hydroxybenzonitrile, IV $=2,6$-dichloro- 3 -hydroxybenzoic acid, $\mathrm{V}=$ 2,6-dichloro-4-hydroxybenzonitrile, $\mathrm{VI}=2$,6-dichloro-4-hydroxybenzoic acid, VII = unknown, VIII = 2,6-dichlorobenzamide, IX = 2,6-dichlorobenzoic acid.

The herbicides used in forests are in the Federal Republic of Germany classificated to three categories according to their toxicity to bees. In this category dichlobenil is held as a herbicide dangerous to the bees and chlorthiamid as a herbicide less dangerous to the bees (BOSSEL 1974).

2. The effects of chlorthiamid and dichlobenil on microorganisms

\subsection{The review of literature}

The effect of dichlobenil on the "total" number of bacteria in the soils is not clear. NIKOLOVA and BAKALIVANOV (1972) found dichlobenil to reduce the number of soil bacteria, but some other investigators have reported that dichlobenil increased bacterial numbers in soil (MITSEV and BOUBALOV 1972) and in water (CAMPER and SHIVELY 1974).

Chlorthiamid is known to inhibit soil nitrification (DEBONA and AUDUS 1970, HELWEG 1972, MARSH and DAVIES 1978) and the inhibition affects the nitrification process itself rather than the nitrification bacteria Nitrosomonas and Nitrobacter (DEBONA and AUDUS 1970).

Soil urease and dehydrogenase are also known to be inhibited by chlorthiamid and dichlobenil (WALTER 1970), and in addition chlorthiamid inhibits soil respiration (WALTER 1970, HELWEG 1972, MARSH and DAVIES 1978).

The numbers of some groups of soil microbes have been found to decrease due to the influence of dichlobenil. Soil fungi are inhibited by dichlobenil (MITSEV and BOUBALOV 1972, NIKOLOVA and BAKALIVANOV 1972) and the numbers of 
cellulolytic microorganims (MITSEV and BOUBALOV 1972) and of actinomycetes (NIKOLOVA and BAKALIVANOV 1972) were also decreased in the presence of dichlobenil.

\subsection{The methods for studying the effects of herbicides on microorganisms}

The effects of the herbicides chlorthiamid and dichlobenil on microorganisms was partly studied with the aim of finding a microbiological method for dichlobenil. Parts of this study have been published earlier (HEINONEN 1976).

BEYNON et al. (1966 b), GRIFFITHS et al. (1966), MEULEMANS and UPTON (1966) and HERZEL (1980) have described a gas chromatographic method for dichlobenil analysis using an electron capture detector. The gaschromatographic method is rapid but the apparatus is still expensive.

The biological assay using Sorgbum vulgare as test organism (PARKER 1964) did not give good results, probably because of weak germination of the test plant. The other available biological method, developed by the Plant Growing Institute of the Netherlands (NIKOLOVA and BAKALIVANOV 1972), requires four weeks because of the long growing time of the test organism Phaseolus vulgaris.

\subsubsection{The selection of microorganisms}

In this work bacteria, especially actinomycetes, were chosen as microbiological indicators for the development of a dichlobenil assay method because they are easier to maintain than the fungi which may be sensitive to dichlobenil. The cellulolytic microorganisms were rejected because cellulolysis is always a rather slow process.

Although the indicator organism must be sensitive to the herbicide it must not on the other hand be sensitive to the possible metabolites of the active component, because these would disturb the assay if present.

For the preliminary tests various members of Actinomycetales belonging to the following genera were chosen: Mycobacterium (6), Nocardia (1), Streptomyces (154) and 102 unidentified actinomycetes. In addition other bacteria of the genera Aeromonas (1), Agrobacterium (2), Artbrobacter (2), Azotobacter (5), Bacillus (2), Chromobacterium (1), Corynebacterium (1), Enterobacter (1), Escherichia (21), Flavobacterium (1), Proteus (1), Pseudomonas (1), Rhizobium (1), and Xanthomonas (1) were tested as well as a yeast of the genus Candida (1) and fungi of the genera Gliocladium (1) and Trichoderma (1). The organisms that according to the eighth edition of Bergey's Manual (BUCHANAN and GIBBONS 1974) belonged to the order Actinomycetales were considered as actinomycetes. The unidentified actinomycetes were isolated from sandy soil (pH 5.3) at Laukaa, Finland. This soil has never been treated with dichlobenil or chlorthiamid. All the other cultures were from the Collection of Microbial Cultures at the Department of Microbiology, University of Helsinki.

\subsubsection{The methods for studying the effects of berbicides on the growth of the microorganisms}

The microorganisms were cultivated in rectangular dishes $(173 \times 390 \mathrm{~mm})$ in a medium containing per litre: $10 \mathrm{~g}$ starch, $1 \mathrm{~g}$ casein, $0.5 \mathrm{~g} \mathrm{~K}_{2} \mathrm{HPO}_{4}$ and $15 \mathrm{~g}$ agar, pH 7.0-7.5 (WAKSMAN 1967). Dichlobenil (Fluka AG, Chemische Fabrik, 
purum) was added as an unsterilized acetone (Merck, p. a.) solution with a gradient concentration of $0-20 \mathrm{mg} / \mathrm{kg}$.

The dichlobenil concentration gradient was made so that the concentration was $0 \mathrm{mg} / \mathrm{kg}$ on one long side of the dish and $20 \mathrm{mg} / \mathrm{kg}$ on the other long side, according to the method of SZYBALSKI and BRYSON (1952). The dish was left overnight before inoculation in order to allow evaporation of the acetone. It was possible to cultivate eight strains in one dish, with two streaks of each strain. The incubation temperature was $28^{\circ} \mathrm{C}$. The possible inhibition of growth on the dichlobenil gradient was estimated after 2, 3 and 4 days.

The gradient technique is rapid but not very exact, because it is difficult to make an even gradient, especially if the solubility of the substance studied is low.

The strains found sensitive in the preliminary test were cultivated as streaks on the starch-casein medium with dichlobenil concentrations of $0,5,10,20$ and 50 $\mathrm{mg} / \mathrm{kg}$ in glass Petri dishes (d $90 \mathrm{~mm}$ ). The growth was evaluated using the markings,,-+++ and +++ after $1,2,3$ and 6 days.

The most sensitive strains in this second test (all spore forming actinomycetes) were selected for a third test. The inoculum was grown on starch-casein agar slants ( $5 \mathrm{ml}$ medium in a $17 \times 152 \mathrm{~mm}$ test tube). Actinomycete spores were detached with $1 \mathrm{ml}$ of water and $0.1 \mathrm{ml}$ aliquots were suspended in $100 \mathrm{ml}$ of $0.01 \%$ sodium laurylsulphonate solution to provide an even spore suspension (WILLIAMS and CROSS 1971). After this $0.1 \mathrm{ml}$ of the sodium laurylsulphonate spore suspension was diluted in $100 \mathrm{ml}$ of $1 \%$ molten $\left(50^{\circ} \mathrm{C}\right)$ agar solution and a Petri dish series containing from 0 to $50 \mathrm{mg} / \mathrm{kg}$ of dichlobenil in solidified agar was inoculated with $3 \mathrm{ml}$ of the molten spore agar by spreading. The colonies (colony forming units) were counted after incubation for 3 days at $28^{\circ} \mathrm{C}$.

The inhibitory effect of some chemical analogues on the most sensitive microorganisms was tested as above. The concentrations tested were $0,1,3,5$ and $10 \mathrm{mg} / \mathrm{kg}$ for the following compounds: 2-chlorobenzylamide (Fluka AG, pract. ), 2,6-dichlorobenzamide (Ega Chemie KG 97 \%), 2,6-dichloro-3-hydroxybenzamide (Philips-Duphar, laboratory synthesis), 2,6-dichloro-4-hydroxybenzamide (Philips-Duphar, laboratory synthesis), 2-chlorobenzoic acid (Fluka AG, puriss), 2,6-dichlorobenzoic acid (Fluka AG, purum), 2,6-dichlorophenol (Fluka AG, purum), 2-chlorobenzonitrile (Merck-Schuchardt, zur Synthese), 2,6-dichloro3-hydroxybenzonitrile (Philips-Duphar, laboratory synthesis), 2,6-dichloro-4hydroxybenzonitrile (Philips-Duphar, laboratory synthesis). Concentrations of 0,1 , $3,5,10,20,50,100,200,500$, and $1000 \mathrm{mg} / \mathrm{kg}$ were used for benzamide (Fluka AG, purum) and $0,1,3,5,10$, and $20 \mathrm{mg} / \mathrm{kg}$ for dichlobenil in Casoron G (Philips-Duphar, Holland) and for chlorthiamid in Prefix (Shell Chemical Co., USA). All these compounds were added as an unsterilized acetone solution.

Dichlobenil was added either directly in acetone to the starch-casein medium or was first added to soil in order to study the separation procedure. A soil sample of 5 $\mathrm{g}$ was soaked in $10 \mathrm{ml}$ of diethyl ether (Merck, p. a.) overnight, extracted with four ether phases $(10 \mathrm{ml})$ and the extract was dried with anhydrous $\mathrm{Na}_{2} \mathrm{SO}_{4}$ (Merck, wasserfrei zur Analyse), after which the ether was evaporated. Dichlobenil was redissolved in acetone (Merck, p. a.) and added to the starch-casein medium. A similar separation procedure would also be necessary in the possible microbiological assay of dichlobenil.

It is essential that the molten spore agar is the same for the standard and for the 
analysis dishes in the same test series. When dichlobenil was extracted from soil a few contaminants sometimes grew on the medium, but bacterial contaminants were easy to distinguish from the actinomycetes. However, the dishes contaminated with moulds had to be rejected.

\subsubsection{The methods for studying actinomycete ATPase activities}

The ATPase activities were measured with firefly luciferase using the bioluminescence technique. The reagents used were $0.1 \mathrm{M}$ tris-EDTA buffer, $\mathrm{pH}$ 7.75 , NRB solution (Nucleotide Releasing Reagent for Microbial Cells, Lumac AG, Basel), firefly luciferase reagent (LUMIT PM, Lumac AG), and ATP standard $2 \mu \mathrm{g} / \mathrm{ml}$ (Lumac AG). Luciferase enzyme and ATP standard solutions were stored at $-20^{\circ} \mathrm{C}$ until used. The instrument used was a luminometer model 1250 (LKB-Wallac, Turku, Finland). The luminescence was registered on a recorder (Kipp \& Zonen BD 40, Delft, Holland.)

The actinomycetes found to be sensitive to dichlobenil were cultivated for two days on starch-casein agar slants. The cells were detached with $5 \mathrm{ml}$ of tris-EDTA buffer. Dichlobenil in acetone was added so that the final concentration of dichlobenil in the measurement solution was $10 \mathrm{mg} / \mathrm{kg}$. Acetone only was added to the controls. One part of the same cell suspension was used for the ATPase measurement with dichlobenil and one part for the measurement without it. The cell suspension and NRB solution (100 $\mu \mathrm{l}$ of each) were pipetted to a sample cuvette which was immediately placed in the measuring head of the luminometer. The luciferase reagent $(10 \mu \mathrm{l})$ was the injected. The bioluminescence measurement could be started after 3-5 seconds. For the standardization $0.01 \mu \mathrm{g}$ of ATP was added to the mixture of cell suspension and NRB solution before the luciferase reagent was injected. The initial ATPase activity was determinated from the plots during the first 60 seconds. The method was the same as that used by LUNDIN et al. (1976 and 1977). The ATPase relation for each strain was calculated as:

ATPase relation $=\frac{\triangle \text { ATP in dichlobenil solution in } 60 \mathrm{~s}}{\Delta \text { ATP in control solution in } 60 \mathrm{~s}}$

\subsection{Observed effects of dichlobenil and chlorthiamid on microorganisms}

\subsubsection{The effects of berbicides on growth}

In the preliminary test 61 of the 265 actinomycetales tested, one Azotobacter, one Enterobacter and one Flavobacterium showed sensitivity to increasing dichlobenil concentration in the starch-casein medium. In the most extreme cases dichlobenil inhibited growth in concentrations as low as $5-15 \mathrm{mg} / \mathrm{kg}$. More often only the sporulation, rather than the growth, of the actinomycete strains was affected at these low concentrations, and after an incubation time of more than four days the growth inhibition disappeared. The growth on Azotobacter agilis (Biochemical Research Institute, Helsinki) and of Enterobacter cloacae (ATCC 13 047) was reduced very slightly at a dichlobenil concentration of $15 \mathrm{mg} / \mathrm{kg}$ one day after the inoculation. However, in two-day old cultures the growth inhibition had disappeared. The 


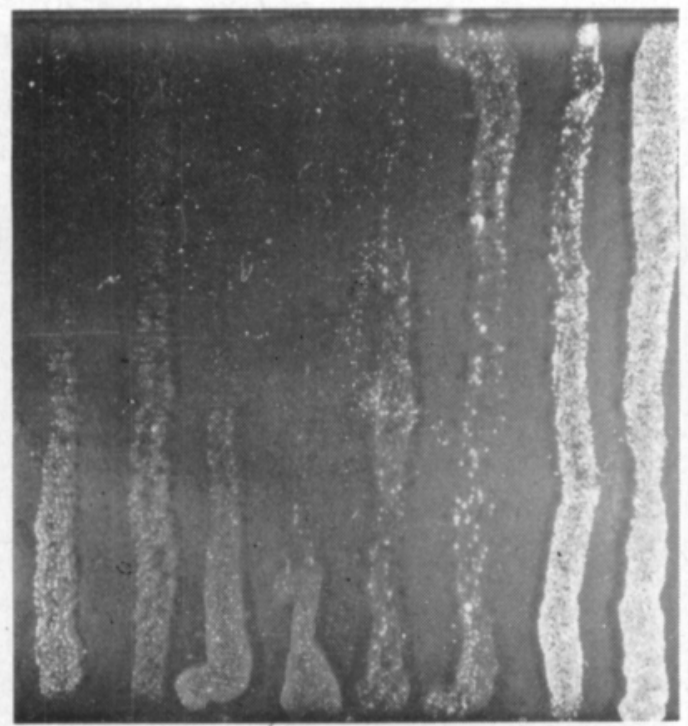

Fig. 4. Two-day old culture of (left to right) Streptomyces kentuckenis, S. alboniger, S. albireticuli and S. virginae growing on the dichlobenil gradient. There are two parallel streaks of each species. The dichlobenil concentration is on the upper edge $20 \mathrm{mg} / \mathrm{kg}$ and on the lower edge $0 \mathrm{mg} / \mathrm{kg}$ (HEINONEN 1976).

growth of Flavobacterium capsulatum (ATCC 14 666) was reduced in one- and twoday old cultures, but after four days' incubation the inhibition effect was no longer discernable.

The sensitive actinomycete strains received from the Collection of Microbial Cultures at the Department of Microbiology, University of Helsinki (34) were retested in a second test. Ten of these showed exceptional sensitivity to dichlobenil. After incubation for one day in the presence of dichlobenil the growth of these strains in Petri dishes was poor (- or +$)$. When the incubation time was prolonged the growth inhibition disappeared only gradually. After six days the growth was either equal to that of the control in all the dishes or slightly weaker in the dish with a dichlobenil concentration of $50 \mathrm{mg} / \mathrm{kg}$. The most sensitive actinomycetes were Streptomyces abikoensis received from the collection of the State Institute of Hygiene, Warsaw, S. albireticuli NRRL B-1670, S. alboniger NRRL B-1832, S. aureus State Institute of Hygiene, Warsaw, S. coelicolor ATCC 10 147, S. flavus State Institute of Hygiene, Warsaw, S. bygroscopicus NRRL, S. virginae NRRL B-1447, Streptoverticillium kentuckenese ATCC 12691 and an unidentified actinomycete.

In the same tests dichlobenil slightly inhibited S. alboniger ATCC 12461 , but had no effect on S. aureus ATCC 3309 and S. aureus "Waksman" or S. flavus "Krainsky" State Institute of Hygiene, Warsaw and S. flavus ATCC 3369 or S. bygroscopicus "Jensen/Waksman" State Institute of Hygiene, Warsaw.

In the third phase of the work five of ten tested actinomycete strains proved to be less useful. These strains were sensitive to dichlobenil but their spores could not be suspended well enough in sodium laurylsulphonate solution, with the result that the actinomycete colony count per dish was almost zero. The effect of dichlobenil on the colony count of the five other strains with the spores suspended well in sodium laurylsulphonate solution, can be seen in Fig. 5 .

The actinomycete colony counts are mean values of two duplicate dishes. Of the strains tested $S$. coelicolor and $S$. virginae were the most sensitive to dichlobenil and could be useful for dichlobenil assay. S. alboniger, S. aureus and S. abikoensis were less 


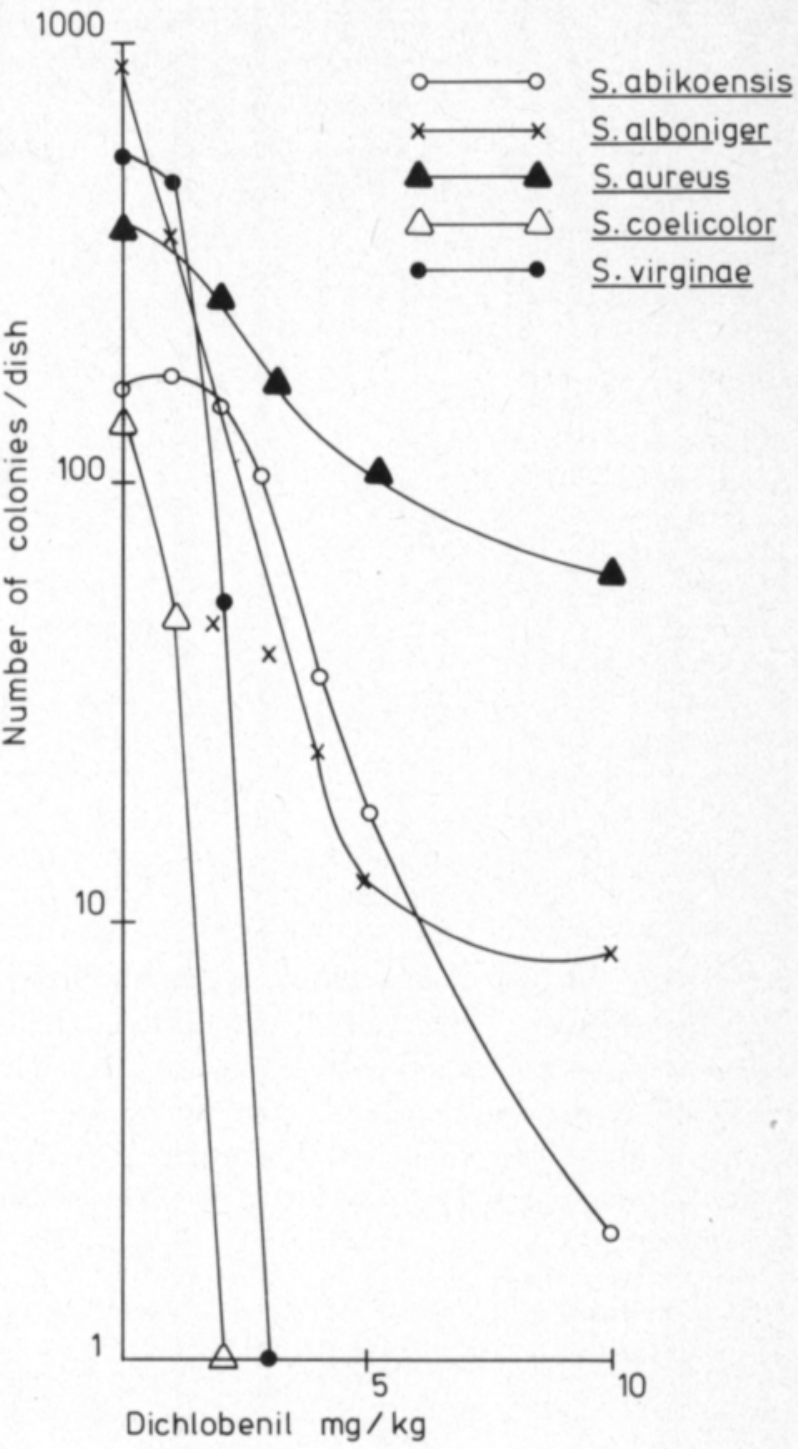

sensitive but also sensitive enough for the dichlobenil extracted from soil.

The sensitivities of the most useful Streptomyces strains to some chlorinated benzoic acid derivatives and benzamide are presented in Table 1 .

Dichlobenil, chlorthiamid, 2-chlorobenzonitrile, 2,6-dichloro-3-hydroxybenzonitrile and 2,6-dichloro-4-hydroxybenzonitrile seemed to have a clear inhibitory effect on the tested Streptomyces strains, dichlobenil having the strongest effect. Even when dichlobenil (Casoron G) was first added to soil, separated and then added to the starch-casein medium, it strongly inhibited tested Streptomyces strains. The effect of benzamide on S. coelicolor was weak. The actinomycete colony counts decreased by $80-85 \%$ with an increase in benzamide concentration from 0 to $1,000 \mathrm{mg} / \mathrm{kg}$.

No clear stimulation by low concentrations of dichlobenil or any other benzoic acid derivative was observed in any of the cultures studied. 
Table 1. Inhibition of the five Streptomyces strains by benzoic acid derivatives. The numbers indicate the lowest concentration $(\mathrm{mg} / \mathrm{kg}$ ) which caused observable inhibition.

\begin{tabular}{|c|c|c|c|c|c|}
\hline Benzoic acid derivatives & Streptomyces & strains & & & \\
\hline & S. abikoensis & S. alboniger & S. aureus & S. coelicolor & S. virginae \\
\hline Benzamide & - & - & - & weak 10 & - \\
\hline $\begin{array}{l}\text { 2-Chlorobenzylamide } \\
\text { 2,6-Dichloro-3-hydroxy- }\end{array}$ & - & - & - & - & - \\
\hline $\begin{array}{l}\text { benzamide } \\
\text { 2,6-Dichloro-4-hydroxy- }\end{array}$ & - & - & - & - & - \\
\hline benzamide & - & - & - & - & - \\
\hline 2-Chlorobenzoic acid & - & - & - & - & - \\
\hline 2,6-Dichlorobenzoic acid & - & - & - & - & - \\
\hline 2,6-Dichlorophenol & - & - & - & - & - \\
\hline $\begin{array}{l}\text { 2-Chlorobenzonitrile } \\
\text { 2,6-Dichloro-3-hydroxy- }\end{array}$ & 10 & - & 5 & 5 & 5 \\
\hline $\begin{array}{l}\text { benzonitrile } \\
\text { 2,6-Dichloro-4-hydroxy- }\end{array}$ & 3 & 3 & 10 & - & 5 \\
\hline benzonitrile & 3 & 5 & 3 & 3 & 5 \\
\hline Dichlobenil in Casoron G & 5 & 3 & 5 & 1 & 3 \\
\hline $\begin{array}{l}\text { Dichlobenil in Casoron G } \\
\text { (added in soil and separated) }\end{array}$ & 3 & 3 & 10 & 1 & 3 \\
\hline Chlorthiamid in Prefix & 5 & 5 & - & 1 & 10 \\
\hline
\end{tabular}

\subsubsection{The effects of dicblobenil on ATPase activities}

The effects of dichlobenil on ATPase activities were studied for nine actinomycete strains found to be sensitive to dichlobenil. The relationships between ATPase activities in the presence and absence of dichlobenil are presented in Table 2. In all these cases dichlobenil retarded the degradation of ATP. Dichlobenil inhibited most strongly the ATPase of Streptomyces coelicolor, S. alboniger and S. bygroscopicus.

Table 2. Relationships between the ATPase in dichlobenil solution and that in control solutions for six actinomycete strains. The control is 100 .

\begin{tabular}{lc}
\hline Actinomycete & Relation of ATPases \\
\hline & \\
Streptomyces albireticuli NRRL B-1670 & 92 \\
S. alboniger NRRL B-1832 & 64 \\
S. aureus "Warsaw" & 82 \\
S. coelicolor ATCC 10 147 & 46 \\
S. bygroscopicus NRRL & 66 \\
Streptoverticillium kentuckenese ATCC 12691 & 84 \\
\hline
\end{tabular}

In the case of Streptomyces abikoensis, S. flavus and S. virginae it was impossible to measure the ATPase activities because the initial ATPase was too unlinear.

2.4. Discussion of the effects of herbicides on microorganisms

The work described in this and the foregoing section was based mainly on the effects of dichlobenil on microorganims, especially actinomycetes. Because chlorthiamid is known to degrade rapidly to dichlobenil in soil (BEYNON et al. 
1966 b), the results can in any case be applied to chlorthiamid. The Streptomyces strains tested were sensitive to both chlorthiamid and dichlobenil. In fact the observed effects of chlorthiamid on microorganisms are very probably the effects of dichlobenil, because probably the chlorthiamid in the medium had transformed partly to dichlobenil before and during the incubation period. The ability of the Streptomyces strains studied to transform chlorthiamid to dichlobenil was not investigated.

Some Streptomyces strains could be used to assay dichlobenil level in a medium because these strains were very sensitive to dichlobenil and their spores suspended easily to form a homogenous inoculum. S. coelicolor ATCC 10147 and S. virginae NRRL B-1 447 could be used for lower concentrations of dichlobenil and S. aureus State Institute of Hygiene, Warsaw, S. alboniger ATCC 12461 and S. abikoensis State Institute of Hygiene, Warsaw, for higher concentrations. S. coelicolor could be used to assay chlorthiamid at lower concentrations and S. abikoensis, S. alboniger and possibly $S$. virginae at higher concentrations. The number of actinomycete colony counts (colony forming units) on the zero-concentration dishes should be between 100 and, 1,000. If the colony count is too high precise counting is difficult and if it is too low the statistical error will be too high.

The bioassay of dichlobenil using plants can be applied directly to the soil to be analysed without any preliminary procedure, but the microbiological bioassay requires a separation procedure similar to that employed in the gas chromatographic methods but simpler. A clean-up of the sample may not be necessary. The separation procedure for the microbiological assay could be cheaper and easier because the purity of the solvents need not be so high and it is not necessary to redistil them. After separation the microbiological bioassay could be suitable for dichlobenil and chlorthiamid determinations in both soil and water and possibly also in air. The separation procedure for dichlobenil was shown to be satisfactory, because dichlobenil had a similar inhibitory effect on the Streptomyces strains regardless of whether it was added directly to the starch-casein medium or first added to soil, separated and then added to the starch-casein medium. The extraction, drying and evaporating phases required a total of $2-3$ hours working time for a sample series.

It was not possible to distinguish the inhibitory effects of chlorthiamid from those of dichlobenil using either the microbiological assay described or the bioassay using plants. Even in the chemical analysis chlorthiamid may to some extent be transformed into dichlobenil. The possible metabolites tested (Table 1), with the exception of 2-chlorobenzonitrile, 2,6-dichloro-3-hydroxybenzonitrile, and 2,6-dichloro-4-hydroxybenzonitrile, should not disturb the chlorthiamid and dichlobenil assays. The molecular formulae of all these conpounds are so similar that the similar inhibitory effect can readily be understood. If other substances toxic to the Streptomyces strains are also present the assay will of course give an incorrect result, as will also the bioassay using plants in the presence of other herbicides. The combined effect of dichlobenil and its metabolites requires further examination.

The effect of dichlobenil on microbes other than the actinomycetes appeared to be unimportant. Only three other bacteria exhibited slight delay in growth. Even Rbizobium leguminosarum and Azotobacter chroococcum, $A$. indicus and $A$. vinelandii, which are important in nitrogen fixation, were resistant. The possible inhibitory effect of dichlobenil on $A$. agilis on the starch-casein medium was unclear. The effect of dichlobenil on nitrogen fixation also requires further investigation. 
The sensitivity of some Streptomyces strains to dichlobenil seems to be very strain-dependent, because among the species $S$. aureus, $S$. flavus and $S$. bygroscopicus only one of two or three strains tested proved to be very sensitive.

The sensitivities of actinomycetes to dichlobenil were as common among the actinomycetes freshly isolated from soil as among the actinomycetes taken from the Collection of Microbial Cultures, Department of Microbiology University of Helsinki. More than $20 \%$ of actinomycetes tested in both these groups were sensitive to dichlobenil.

A very interesting question remaining is of course the reason why some actinomycetes are so sensitive to dichlobenil. At least with some actinomycetes dichlobenil disturbs the energy metabolism which could be seen in the decrease of the ATPase activity (Table 2). A similar decrease of ATPase caused by dichlobenil, 2,6-dichloro3-hydroxybenzonitrile, and 2,6-dichloro-4-hydroxybenzonitrile has been reported by MORELAND el al. (1974) in mitochondria of mung bean (Phaseolus aureus) hypocotyls.

The inhibition of dichlobenil and some related compounds especially disturbs or at least delays sporulation. Because the actinomycete spores are mainly reproductive bodies (WAKSMAN 1967), it is easy to understand that a substance inhibiting sporulation would also decrease the number of actinomycetes in soil.

The fact that dichlobenil inhibits or delays the growth of some microorganisms in an artificial starch-casein medium does not mean that it would inhibit the growth of the same microorganisms in the field to the same extent, because soil particles may protect microorganisms from direct contact with pesticides. Thus the inhibitory effects in soil cannot be determinated so easily. The distribution of pesticides in soil is always more uneven than in agar solutions. Concentrations may be much higher on the surface of some soil particles than in the surrounding soil. Sensitive microorganisms in these circumstances will either die or more probably they will be prevented from growing even in the presence of sufficient nutrients.

Since dichlobenil inhibits the growth of actinomycetes, the ecological significance of this phenomenon may be especially high in northern regions where counts and species numbers of actinomycetes are often low (MISHUSTIN 1975). This question should be studied in northern forests where dichlobenil is used as a herbicide.

3. The effect of microorganisms on the herbicides chlorthiamid and dichlobenil

\subsection{Literature review}

The role of microorganisms in the degradation of the herbicides chlorthiamid and dichlobenil in soil has been discussed in the literature. It is well known that chlorthiamid degrades rapidly to dichlobenil and dichlobenil in turn to 2,6-dichlorobenzamide (BEYNON and WRIGHT 1968 a, BRIGGS and DAWSON 1970, VERLOOP and NIMMO 1970).

In the investigation carried out by VERLOOP and NIMMO (1970), dichlobenil degraded to 2,6-dichlorobenzamide in unsterilized soil but not in heat-sterilized soil, while BRIGGS and DAWSON (1970), however, found dichlobenil to degrade as rapidly in azide-treated as in unsterilized soil when they studied the degradation in 
many different types of soil. The latter authors therefore concluded that the degradation was non-biological.

Regardless of whether the transformation of dichlobenil to 2,6-dichlorobenzamide is microbiological or non-biological, the transformation rates were in these two laboratory studies approximately the same. One third of the dichlobenil was transformed within three months and almost half within six months.

After 2,6-dichlorobenzamide, the next degradation product of dichlobenil is 2,6-dichlorobenzoic acid. SHEETS et al. (1968) found a small amount of this compound in greenhouse soils, but PATE and FUNDERBURK (1966) reported Fusarium and some other fungi to metabolize dichlobenil in 45 days to 2,6-dichlorobenzoic acid as the only metabolite, contrary to many other reports in the literature.

FOURNIER (1972, 1974, 1975) and FOURNIER and CATROUX (1972) studied the metabolism of benzamide and mono- and dichlorinated benzamides very thoroughly in the laboratory. Benzamide, monochlorinated benzamides, 2,5-dichlorobenzamide and 3,5-dichlorobenzamide, when present as the only nitrogen source, were utilized by some Aspergillus species, but 2,6-dichlorobenzamide was not. The metabolic products of these benzamides were the corresponding benzoic acids (FOURNIER 1972, FOURNIER and CATROUX 1972).

In later studies FOURNIER $(1974,1975)$ found ${ }^{14} \mathrm{C}$-2,6-dichlorobenzamide to degrade to a small extent to ${ }^{14} \mathrm{C}$-2,6-dichlorobenzoic acid in unsterilized soil in laboratory trials. Very small amounts of ${ }^{14} \mathrm{CO}_{2}$ were liberated from ${ }^{14} \mathrm{C}-2,6$-dichlorobenzamide in organic soil-water suspension. The amount of ${ }^{14} \mathrm{CO}_{2}$ liberated was higher if benzamide was added. The addition of glucose had no effect. The addition of non-radioactive 2,6-dichlorobenzamide caused a proportional reduction in the liberation of ${ }^{14} \mathrm{CO}_{2}$, because the total capacity of soil to degrade 2,6-dichlorobenzamide remained unchanged and the ratio ${ }^{14} \mathrm{CO}_{2}:{ }^{12} \mathrm{CO}_{2}$ was therefore reduced. No enzyme adaptation or enrichment of degrading microorganisms was observed. The degradation appears to have been effected by cometabolism. FOURNIER $(1974,1975)$ used in his experiments $15 \mathrm{mg}$ or $4 \mathrm{mg}$ 2,6-dichlorobenzamide in $1 \mathrm{~kg}$ of soil. Only approximately $5 \%$ of this degraded to produce ${ }^{14} \mathrm{CO}_{2}$ in $2-4$ months.

VERLOOP and NIMMO (1972) and NIMMO and VERLOOP (1975) have studied the degradation rates of dichlobenil in different soils. In their experiments the half-life of dichlobenil varied in the laboratory from 4 to 60 weeks. The degradation was most rapid in some neutral clay soils and was slowest in acidic, humuspoor, sandy soil.

Microorganisms also produce some other metabolites from chlorthiamid. In addition to dichlobenil and 2,6-dichlorobenzamide, BEYNON and WRIGHT (1968 a) found two minor unidentified products in soil, while VERLOOP and NIMMO

Fig. 6. The microbiological metabolism of chlorthiamid according to FOURNIER $(1974,1975)$ and NIMMO and VERLOOP (1975).
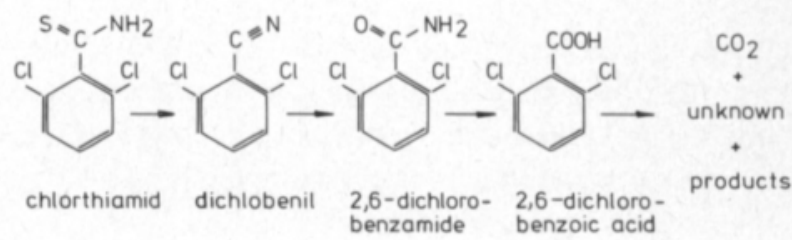
Table 3. Compounds which have given negative results agains some reference compounds in the thin layer chromatographic analysis of unknown minor metabolites of chlorthiamid and dichlobenil.

\begin{tabular}{llll}
\hline \multirow{3}{*}{ Compound } & Reference & & \\
\cline { 2 - 4 } & BEYNON & VERLOOP and & FOURNIER \\
& WRIGHT (1968 a) & NIMMO (1970) & $(1972)$ \\
\hline
\end{tabular}

2,6-Dichloro-3-hydroxythiobenzamide

2,6-Dichloro-3-hydroxybenzonitrile

2,6-Dichloro-3-hydroxybenzamide

2,6-Dichloro-3-hydroxybenzoic acid

2,6-Dichloro-3-hydroxybenzaldehyde

2,6-Dichloro-4-hydroxybenzonitrile

2,6-Dichloro-4-hydroxybenzamide

2,6-Dichlorobenzonitrile oxide

2,6-Dichlorobenzylamine

2,6-Dichlorobenzaldehyde

2,5-Dichlorobenzamide

3,5-Dichlorobenzamide

(1970) found 2,6-dichlorobenzamide and three unidentified minor metabolites. FOURNIER (1972) found 2,6-dichlorobenzamide to produce 2,6-dichlorobenzoic acid, $\mathrm{CO}_{2}$ and three unknown metabolites, as also did MIYAZAKI et al. (1975).

In all these four reports radioactive matter was used and the radioactive label was in the same position in the molecules, i.e. in the carbon atom of the side chain of chlorthiamid, dichlobenil or 2,6-dichlorobenzamide. Thus all the unknown metabolic products still contained ${ }^{14} \mathrm{C}$. In all cases the total amounts of the unknown products were small, only a few precent of the total products.

BEYNON and WRIGHT (1968 a), VERLOOP and NIMMO (1970) and FOURNIER (1972) attempted to analyze the unknown products with the aid of thin layer chromatography. A summary of the tested compounds which gave negative results in shown in Table 3.

\subsection{Materials and methods}

\subsubsection{General principles for investigations of cometabolic pesticide degradation capacity by microorganisms}

Cometabolism has been found to be the mode of degradation of many synthetic, recalcitrant compounds, including many pesticides. ATLAS and BARTHA (1981) defined cometabolism as a phenomenon occurring when a compound is transformed by a microorganism but the microorganism is unable to grow on the compound and does not derive energy, carbon or any other nutrient from the transformation.

When a pure culture of microorganisms is added to a suitable growth medium with a true carbon source the number of microorganisms will decrease. However, if microorganisms are added to a growth medium containing a compound to be degraded by cometabolism, as a sole carbon source, microorganisms will not grow and the amount of the recalcitrant, cometabolic compound will not change.

The cosubstrate, i. e. the compound to be degraded by cometabolism, can be degraded only if a suitable true carbon source is present. Usually the true carbon 
source and the cosubstrate resembele each others chemically, as do e. g. benzoate and 2,3,6-trichlorobenzoate (HORVATH and ALEXANDER 1970, HORVATH 1972). The microorganism is producing enzymes for the degradation of the true carbon source and all its intermediate compounds. The cosubstrate resembles so closely the true carbon source that it is transformed by the first metabolic enzyme to the first intermediate product of its own degradation pathway. In pure cultures this first intermediate product will probably accumulate because the second enzyme involved in the degradation of the true carbon source probably is more specific. In mixed culture, as in the soil, the cosubstrate can be sequentially degraded by many microorganisms using many different enzyme systems so the degradation could be more complete.

The reaction rate of the cometabolic degradation is constant, because no increase of degrading microorganisms (no increase of degrading enzymes) happens. The degradation process continues only as long time as there is a true carbon source and the other nutrients for the cometabolic degradation.

Since there are no reports in the literature of microorganisms degrading dichlobenil metabolically, it seems most possible that the degradation may be a cometabolic process. If so, there must be a true carbon source essential for the metabolism, or rather the cometabolism, of the cosubstrate.

\subsubsection{Isolation and identification of microorganisms}

The microorganisms potentially capable of degrading chlorthiamid and dichlobenil were isolated from greenhouse soil, which had been treated twice with a commercial chlorthiamid formulation (Prefix, Shell International Chemical Co, London). The first treatment was applied three months and the second two and half months before the isolation. The amount of Prefix was in each treatment $2 \mathrm{~kg} / \mathrm{ha}$. Pretreatments of soil with herbicide may be useful because of the possible enrichment of herbicide-degrading (CULLIMORE 1971) or herbicide-resistent microorganisms in soil.

The enrichment medium contained per litre: $1 \mathrm{~g} \mathrm{~K}_{2} \mathrm{HPO}_{4}, 1 \mathrm{~g} \mathrm{NH}{ }_{4} \mathrm{NO}_{3}, 0.1$ $\mathrm{g} \mathrm{NaCl}, 0.05 \mathrm{~g} \mathrm{MgSO}_{4} \cdot 7 \mathrm{H}_{2} 0,50 \mathrm{mg}$ dichlobenil (Fluka AG, purum), $2 \mathrm{~g}$ carbon source and $250 \mathrm{ml}$ soil extract obtained according to the method of Smith and Dawson (BOOTH 1971). The carbon source was 2,6-dichlorobenzoic acid in medium A and benzamide in medium B. Soil extract may also contain utilizable carbon. Dichlobenil was used as a cosubstrate. Dichlobenil and 2,6-dichlorobenzoic acid or benzamide were added separately in unsterilized acetone which was then evaporated.

The media were inoculated with $0.5 \mathrm{~g}$ of soil pretreated with herbicide and incubated at $28{ }^{\circ} \mathrm{C}$ for $4-10$ days on a gyrotory shaker at $220 \mathrm{rpm}$ (New Brunswick Co, Brunswick, N. J.). The microorganisms were enriched by three growth passages in the same culture medium.

Pure microbial cultures were isolated by the autoradiographic technique described by GROSSBARD (1970) and KOKKE (1970). The agar media were similar to the media used in the enrichment except that they contained per litre $15 \mathrm{~g}$ agar and that ${ }^{14} \mathrm{C}$-labelled chlorthiamid (Shell, Sittingbourne England, specific activity $9.7 \mu \mathrm{Ci} / \mathrm{mg}$ and purity $99.5 \%$ ) was substituted for $10 \%$ of the total herbicide. ${ }^{14} \mathrm{C}$-label was in the carbon outside the aromatic ring. The radioactivity of a Petri dish (20 ml agar) was thus $1 \mu \mathrm{Ci}$. The media were inoculated with 
enrichment culture of the third passage and incubated at $28^{\circ} \mathrm{C}$ for $1-2$ weeks. The agar with colonies was wrapped in a sterile melinex-membrane (Terinex Ltd, England, thickness $12 \mu \mathrm{m}$ ). An X-ray film (Agfa-Gevaert Structurix DW D4) was then placed over the agar and exposed for 14 days in the dark at $+4{ }^{\circ} \mathrm{C}$. After development of the X-ray film it was observed that some colonies had accumulated radioactivity. These colonies were isolated, since it was reasoned that a microorganism capable of accumulating a substance (the herbicide) may also transform its structure. Some other colonies had decreased the radioactivity of the agar outside the colony liberating a radioactive, volatile metabolite. These colonies were also isolated. Some of the bacterial colonies were contaminated by moulds during the exposure, causing difficulties in isolation. The agar medium A was too acidic and so too fragile for making autoradiographs. All twelve strains growing on medium A were selected for further examinations.

The microbiological purity of the isolated strains was checked, as well as their true ability to accumulate radioactive herbicide in pure cultures. Agar containing radioactive herbicide was inoculated with the strains isolated and after incubation for 1-2 weeks the agar was left to dry for 2-3 weeks in order to prevent disturbance of the X-ray film by water.

The identification of the isolated microbial strains was carried out using information from the following sources: GILMAN (1957), PHAFF et al. (1966), SKERMAN (1967), DAVIS and NEWTON (1969), WEBSTER (1970), BUCHANAN and GIBBONS (1974).

\subsubsection{Investigations of metabolism and cometabolism of 2,6-dicblorobenzoic acid derivatives}

The ability of some of the microorganisms isolated to utilize ortho-chlorinated benzoic acid derivatives as a true carbon source was studied in aerobic cultures, on the gyrotory shaker $(175 \mathrm{rpm})$ or on agar slants at $28^{\circ} \mathrm{C}$.

The basic medium contained per litre: $1 \mathrm{~g} \mathrm{~K}_{2} \mathrm{HPO}_{4}, 1 \mathrm{~g} \mathrm{NH} \mathrm{NO}_{3}, 0.1 \mathrm{~g}$ $\mathrm{NaCl}, 0.05 \mathrm{~g} \mathrm{MgSO}_{4} \cdot 7 \mathrm{H}_{2} 0,50 \mathrm{mg}$ dichlobenil and $2 \mathrm{~g}$ carbon source. For solid media $15 \mathrm{~g}$ agar were added. Dichlobenil and the true carbon source were added separately without sterilization, with the exception of the water-soluble sodium benzoate (Merck, p.a.), which was sterilized by filtration. The $\mathrm{pH}$ of the medium was adjusted to $\mathrm{pH} 6-7.5$ with $\mathrm{NaOH}$, using bromthymol blue $(0.001 \%)$ as an indicator. Sodium benzoate, 2-chlorobenzoic acid (Fluka AG, puriss) and 2,6-dichlorobenzoic acid were tested as carbon sources for the strains isolated on medium A (2,6-dichlorobenzoic acid). Benzamide (Fluka AG, purum), 2-chlorobenzamide (IGN, K \& K. Lab. Inc.) and 2,6-dichlorobenzamide (Ega-Chemie) were tested as carbon sources for some strains isolated on medium B (benzamide) and for five strains isolated on medium A. All the B strains selected grew well on medium B.

2-Chlorobenzamide was tested as carbon source for some bacteria after preliminary cultivation of the organisms for 7-17 days in liquid medium containing $1 \mathrm{~g}$ of benzamide per litre. Then 2-chlorobenzamide ( $1 \mathrm{~g}$ per litre) was added and the increase in growth was followed.

The effect of benzamide concentration on bacterial growth was studied using benzamide concentrations of $0.1,0.5,1.0$ and $2.0 \mathrm{~g}$ per litre. The utilization of benz- 
amide as combined nitrogen and carbon source was studied by omitting $\mathrm{NH}_{4} \mathrm{NO}_{3}$ from the basic medium.

The growth of fungi was estimated visually on agar slants, and in liquid medium by measurement of dry weight. The growth of bacteria and yeasts was estimated by measuring absorbance spectrophotometrically at $345 \mathrm{~nm}$ (Beckman DB).

\subsubsection{Degradation of the berbicides chlortbiamid and dicblobenil}

\subsubsection{The ${ }^{14} \mathrm{C}$-measurements}

The ${ }^{14} \mathrm{C}$-contents were measured by using a liquid scintillation counter (Wallac Decem-NTL 314, Turku, Finland) in a carbon channel. During the counting the scintillation liquid contained a $100 \mu \mathrm{l}$ sample, $1 \mathrm{ml}$ water and $10 \mathrm{ml}$ scintillation solution. Scintillation solutions used were Aquasol (NEN, Boston) or a cocktail containing $40 \mathrm{~g}$ naphtalen (Merck, for synthesis), $4 \mathrm{~g}$ omnifluor (NEN, WestGermany) and 11 dioxane (Merck, p.a.).

An unknown radioactive, gaseous metabolite evolving from the bacterial growth media was analyzed. After incubation for 70 days at $26^{\circ} \mathrm{C}$ a bacterial culture with radioactive basic medium $\mathrm{B}$ and the contents of a liquid scintillation bottle containing $1 \mathrm{ml}$ of $5 \%$ sodium hydroxide to absorb $\mathrm{CO}_{2}$ were added to a chromatography chamber of $3.7 \mathrm{l}$. The chamber was sealed well with silicone stopcock grease. After seven days the chamber was opened and $2.5 \mathrm{ml}$ water and 10 $\mathrm{ml}$ Aquasol were added to the liquid scintillation bottles, which were shaken immediately to obtain an even gel for measurements.

\subsubsection{Chromatographic studies}

The cultivation media used in chromatography were either the radioactive liquid enrichment media $A$ and $B$, in which $10 \%$ of herbicide could be substituted by ${ }^{14} \mathrm{C}$ chlorthiamid, or ${ }^{14} \mathrm{C}$-ring labelled 2,6-dichlorobenzoic acid.

The ${ }^{14} \mathrm{C}$-label of chlorthiamid was in carbon 1 . The specific radioactivity of this medium was only $6.3 \mathrm{nCi}$ per $\mathrm{ml}$. The incubation times at $26^{\circ} \mathrm{C}$ in the rotory shaker $(180 \mathrm{rpm})$ were up to 8 weeks. After cultivation ${ }^{14} \mathrm{C}$-labelled metabolites were analyzed by thin layer chromatography (TLC) with the aid of autoradiography. The aromatic substances were separated from the growth medium by shaking with diethyl ether (Merck, p. a.) at $\mathrm{pH}<2, \mathrm{pH} 5$ and $\mathrm{pH} 11$, three times at each $\mathrm{pH}$ value. The ether phases were combined after which the ether was evaporated. The residue was redissolved in $0.5 \mathrm{ml}$ acetone (Merck, zur Analyse). The radioactivities of some of the extracts from $\mathrm{pH}<2, \mathrm{pH} \mathrm{5,} \mathrm{pH} 11$ and water phase were measured using a liquid scintillation counter. The sample was pipetted to the TLC plate $(20 \times 20 \mathrm{~cm})$ which had been activated overnight at $105^{\circ} \mathrm{C}$. The plate type was silica gel $60 \mathrm{~F}_{254}$ pre-coated, layer-thickness $0.25 \mathrm{~mm}$ (Merck). Development to $15 \mathrm{~cm}$ was at room temperature, usually with $10 \% \mathrm{w} / \mathrm{w}$ ethanol in toluene. The Rf-values were read after development under a UV-analysis lamp (Desaga) at $254 \mathrm{~nm}$ and $366 \mathrm{~nm}$. An X-ray film was placed on the plate and exposed 7 to 30 days in the dark to determine the radioactive spots. The X-ray films used were Agfa-Gevaert Structurix DW D4 and Kodak X-mat H-film XH 1. Standards $(1 \mathrm{mg} / \mathrm{ml})$ were: 
- chlorthiamid from commericial herbicide formulation Prefix

- dichlobenil (Fluka AG, purum)

- benzamide (Fluka AG, purum)

- 2,6-dichlorobenzoic acid (Fluka AG, purum)

- 2,6-dichlorobenzamide (Ega-Chemie KG, 97 \%)

- 2,6-dichlorophenol (Fluka AG, purum)

- 2,6-dichloro-3-hydroxybenzamide (Philips-Duphar, laboratory synthesis)

- 2,6-dichloro-4-hydroxybenzamide (Philips-Duphar, laboratory synthesis)

- 2-chlorobenzonitrile (Merck-Schuchardt, zur Synthese)

- 2-chlorobenzoic acid (Fluka AG, puriss)

- 2-chlorobenzamide (Wolff und Kaaber Trading)

The standards were always necessary. A cochromatography was carried out in the verification tests.

The spots were sprayed with Folin-Ciocalteau reagent to detect the presence of aromatic rings and with silver nitrate-2-phenoxyethanol reagent to demonstrate $\mathrm{Cl}$ content of the spot. Folin-Ciocalteau reagent was used as a commercial preparation (Orion Pharmaceutical Company, Espoo, Finland). After spraying, the plate was exposed 1-2 minutes in ammonia vapour according to the method of EVANS et al. (1971). The silver nitrate-2-phenoxyethanol spraying and the succeeding 15 minute exposure to UV light were carried out according to the method described by SHERMA (1973). Spraying with $10 \% \mathrm{FeCl}_{3}$ was used for detection of catechols (KREBS et al. 1967).

The purity of some radioactive spots was verified by detaching the spots in silica gel with the aid of a razor blade, diluting in acetone and running them in a new, two-dimensional TLC. The development solutions used were ethanol in toluene (10 and $20 \% \mathrm{w} / \mathrm{w})$, chloroform + ethanol + acetic acid $(89: 10: 1$ at room temperature) and acetone in hexane (10 and $20 \% \mathrm{w} / \mathrm{w})$, ethanol in benzene ( $5 \%$ $\mathrm{w} / \mathrm{w})$ and chloroform.

The radioactivities of selected spots were measured by liquid scintillation counting method after the radioactive spots were detached to a scintillation bottle. The dioxane scintillation solution was added and radioactivity was measured.

\subsubsection{Gas chromatographic analyses}

Gas chromatographic analyses were carried out from ether extracts redissolved in dichlormethan (BDH AnalaR) or from TLC spots transformed to ethanol 99,5\% (Finnish State Alcohol Monopol, AaS). Non-volatile compounds such as carboxylic acid were ethylated with ethanol using $\mathrm{N}, \mathrm{N}$-dicyclohexylcarbodiimide (Fluka, puriss) and pyridine as reagents according to the method of FELDER et al. (1973 a, b). A Carlo Erba Fractovrap gas chromatograph equipped with a flame ionization detector was used. The columns used were $35 \mathrm{~m}$ or $25 \mathrm{~m}$ glass capillary columns, type Carbowax 20. The carrier gas was hydrogen. The operations were carried out by using a temperature programming from $80^{\circ} \mathrm{C}$ to $220^{\circ} \mathrm{C}$ or isothermically at $154^{\circ} \mathrm{C}$. The detection limits for standard compounds were $<50 \mathrm{ng}$.

\subsubsection{Mass spectrometry analyses}

Mass spectrometry analyses were carried out by Mrs. Kirsti Kaustia M. Sc., of the Chemistry Laboratory of the Technical Research Centre of Finland and Mr. Seppo Räisänen Lic. Sc., of Instrument Centre for Chemistry, University of 
Helsinki, using a mass spectrometer equipped with glass capillary gas chromatograph and mass fragmentograph (JEOL - D 100). The samples for mass spectral analyses were separated and purified by TLC and then either redissolved in ethanol or ethylated as for gas chromatography.

\subsubsection{Gel filtration studies}

The media of two bacterial strains (medium B with radioactive chlorthiamid) were studied by gel filtration using the gels Sephadex G 10 and Sephadex LH 20 (both from Pharmacia Fine Chemicals AB, Sweden). The buffer solution was phosphate buffer of $\mathrm{pH} 7$ and ionic strength 0.05 (LONG 1961). The column height was $32 \mathrm{~cm}$ and the diameter $2.5 \mathrm{~cm}$, and the flow rate was $22 \mathrm{ml} / \mathrm{h}$.

The filtrate was collected in $5 \mathrm{ml}$ fractions by a fraction collector (LKB, Sweden).

The radioactivities of the fractions were measured by the liquid scintillation counter. The radioactive peaks were also analyzed by TLC using $10 \% \mathrm{w} / \mathrm{w}$ ethanol in toluene as solvent.

\subsubsection{2,6-Dichlorobenzamide amidase test}

The amidase activity of 2,6-dichlorobenzamide was tested by a method based on the work of ARAI et al. (1970). Bacterial inoculum was first grown on nutrient agar (Oxoid). The amidase medium contained per litre: $5 \mathrm{~g} \mathrm{NaCl}, 2 \mathrm{~g} \mathrm{KH}_{2} \mathrm{PO}_{4}, 1$ g 2,6-dichlorobenzamide and $0.1 \mathrm{~g} \mathrm{MgSO}_{4} \cdot 7 \mathrm{H}_{2} \mathrm{O}$. The $\mathrm{pH}$ was adjusted to $\mathrm{pH}$ 6.8. Aliquots of $1 \mathrm{ml}$ of the medium were transferred to glass tubes and sterilized at $110^{\circ} \mathrm{C}$ for $10 \mathrm{~min}$. The tubes were inoculated with a dense bacterial suspension. After one and three days' incubation at $28^{\circ} \mathrm{C}$ one drop of Nessler reagent (Orion Pharmaceutical Company, Espoo Finland, $\mathrm{Ph}$. Nord.) was added.

\subsubsection{Dechlorination test for dichlobenil and some related compounds}

Some bacterial strains which grew well in medium B were selected for dechlorination tests.

The growth medium was based on medium B, from which chloride was, however, omitted. The composition per litre was: $2 \mathrm{~g}$ benzamide, $1 \mathrm{~g} \mathrm{~K}_{2} \mathrm{HPO}_{4}, 1 \mathrm{~g}$ $\mathrm{NH}_{4} \mathrm{NO}_{3}, 0.05 \mathrm{~g} \mathrm{MgSO}_{4} \cdot 7 \mathrm{H}_{2} \mathrm{O}, 50 \mathrm{mg}$ chlorinated compound, $750 \mathrm{ml}$ water and $250 \mathrm{ml}$ soil extract. The chlorinated compound and benzamide were added separately in unsterilized acetone which was evaporated before the addition of any other substances. Dichlobenil was tested as chlorinated compound for 37 bacteria isolated. 2,6-Dichlorobenzoic acid, 2,6-dichlorobenzamide, 2,6-dichlorophenol and 1,3-dichlorobenzene were tested as chlorinated compounds only for those bacteria which liberated $\mathrm{Cl}^{-}$from dichlobenil.

The chloride ion concentrations of the supernatants of inoculated growth media were determined after incubation for $0,1,3,7,14$ and 21 days in the rotory shaker $(175 \mathrm{rpm})$ at $28^{\circ} \mathrm{C}$. The flasks were not protected from light in the incubation room. Prior to sampling the cultures were taken to an illuminated laboratory for less than one hour. Uninoculated growth media were used as blanks. Chloride ion concentration was determinated by titrating $5 \mathrm{ml}$ of growth medium supernatant with $1 \mathrm{mM}$ mercuric nitrate at $\mathrm{pH} 2.5$ by using diphenylcarbazone and bromophenol blue as mixed indicator according to the Finnish official method of 
water analysis (ANON. 1968).

The need for a longer incubation time than 21 days was checked for a few bacterial strains with the highest levels of chloride production by incubating these bacteria in a medium containing dichlobenil for 28 or 35 days and determining the chloride ion concentration in the medium.

The need for oxygen in the dechlorination of dichlobenil was also investigated. Aerobic cultivations were carried out in conical flasks closed with cotton plugs. The anaerobic cultivations were carried out in $100 \mathrm{ml}$ water sample bottles closed tightly with a screw cap. Inoculation and all samplings were performed under nitrogen.

The argentometric method for chloride determination could not be used because of the high phosphate concentration of the growth medium. The ferric ion content of the growth medium did not interfere with the mercuric nitrate titration because it will be bound to the phosphate in the medium.

\subsubsection{Ring cleavage examinations}

Ring fission was studied by Warburg manometry. The test was performed using 15 bacterial strains growing well in medium B. The bacterial cells were cultivated on agar isolation medium B, washed with water three times and suspended in $0.5 \mathrm{ml}$ water. Substrate solution $(2 \mathrm{ml})$ was added to the main cup of the Warburg bottle and $0.2 \mathrm{ml}$ of $20 \% \mathrm{KOH}$ and a piece of folded filter paper were added to the small central cup. After an equilibrium time of $15-20 \mathrm{~min}$ the cells were added to the side cup. The manometers were closed and the cells were poured carefully into the substrate. In other respects the manometric work was carried out in accordance with UMBREIT et al. (1957). The incubations were at $28^{\circ} \mathrm{C}$ under shaking and incubation times varied from 4.5 to $25 \mathrm{~h}$. The substrate solutions contained per 1 litre of water: a) $50 \mathrm{mg}$ dichlobenil, b) $50 \mathrm{mg}$ dichlobenil $+200 \mathrm{mg}$ benzamide, c) $200 \mathrm{mg}$ benzamide, d) $200 \mathrm{mg}$ 2,6-dichlorobenzamide and e) $50 \mathrm{mg}$ dichlobenil + $200 \mathrm{mg}$ 2,6-dichlorobenzamide. 2-Chlorobenzamide, 2,6-dichloro-3-hydroxybenzamide and 2,6-dichloro-4-hydroxybenzamide, all $200 \mathrm{mg}$ in 1 litre of water, were tested as substrates for one of the best strains.

The aromatic ring cleavage mechanisms were tested by Rothera tests according to the instructions of HOLDER and COLLEE (1971). The bacterial cells were cultivated on agar medium $\mathrm{B}$, washed with $0.02 \mathrm{M}$ tris buffer $\mathrm{pH} 8.0$ (AUGUSTINSSON 1966) and suspended in $2 \mathrm{ml}$ buffer, to which $0.5 \mathrm{ml}$ toluene and $1 \mathrm{ml}$ of $20 \mathrm{mM}$ substrate solution were added. The cells and the substrate were shaken on the gyrotory shaker $(175 \mathrm{rpm})$ for $1-24 \mathrm{~h}$ and the colour was checked. A yellow colour due to muconic semialdehyde indicated meta cleavage. After the incubation $1 \mathrm{~g}\left(\mathrm{NH}_{4}\right)_{2} \mathrm{SO}_{4}, 0.1 \mathrm{ml} 1 \%$ sodium nitroprusside and $0.5 \mathrm{ml}$ concentrated $\mathrm{NH}_{3}$ were added. A violet colour of $\beta$-ketoadipate indicated ortbo cleavage. 3,4-Dihydroxybenzoic acid, salicylic acid and 3-chlorocatechol (a gift from professor Knackmuss) were tested as substrates.

To detect catechol compounds in the cultures a colour test was performed according to the method of EVANS (1947). In this test catechols give in acidic solution a yellow colour with $\mathrm{Na}_{2} \mathrm{WO}_{4}$ in the presence of $\mathrm{NaNO}_{2}$. In alkaline solution the colour turns to cherry red. Benzoic acid, 2-chlorobenzoic acid and 2,6-dichlorobenzoic acid were used as carbon sources in these cultures. The $\mathrm{pH}$ was adjusted to $6.0-7.0$ and the media were inoculated very heavily with microbial cells. The tests were performed after incubations of 1, 2, 6, 14, 22 and 31 days. 


\subsection{Results}

\subsubsection{Characterization of microorganisms isolated}

Twelve strains growing on acid medium A and 56 on medium B were isolated for further examination.

Thirty Gram-variable, non-sporing, pleomorphic, not acid-fast, aerobic coccoid to rod-shaped bacteria were isolated from medium $B$. They were all catalase positive but indole negative and Voges-Proskauer negative. Some of them utilized glucose oxidatively, none fermentatively. They did not attack cellulose but most of them hydrolyzed starch and gelatin. They were considered to be members of the genus Artbrobacter.

Five strains isolated from medium A and twelve from medium B were Grampositive, aerobic, spore-forming Bacillus sp.

Eleven strains isolated from medium B were Gram-positive or Gram-variable, pleomorphic, not acid-fast, facultatively anaerobic, catalase positive bacteria. This coryneform group was not further identified.

One Gram-negative bacterium isolated from medium B was a yellow, aerobic, non-sporing rod, motile with peritrichous flagella. It utilized glucose oxidatively and was catalase positive, but oxidase negative. It did not reduce nitrate to nitrite, but hydrolyzed casein. This bacterium was supposed to be a Flavobacterium sp.

One white, Gram-negative, non-sporing, long rod-shaped bacterium isolated from medium B was motile with peritrichous flagella. It fermented glucose and produced acid from lactose and dulcitol. No gas-production could be detected. It was oxidase negative and catalase positive and could hydrolyze starch and casein but not gelatin. It did not reduce nitrate to nitrite. This bacterium was not further identified.

One of the microorganisms isolated from medium B was a red-pigmented actinomycete with powdery colonies and aerial mycelium.

One yeast isolated from medium A had red, oval, unicellular cells. It utilized glucose oxidatively, but not inositol. It was identified to the genus Rbodotorula.

Three fungal strains isolated from medium A were on their morphological bases assigned to the genus Penicillium.

Three moulds from medium A produced greenish mycelium. One of these organisms was cellulolytic. They were assigned to the genus Trichoderma because of the morphology of the conidiophores and conidia.

In the autoradiographic study 37 of the $56 \mathrm{~B}$-strains accumulated ${ }^{14} \mathrm{C}$ from carbonyl labelled chlorthiamid rather well and 3 only slightly. Sixteen B-strains did not grow appreciably or did not accumulate radioactivity.

\subsubsection{Degradation of 2,6-dichlorobenzoic acid compounds}

Thirteen Artbrobacter strains growing very well in medium B were selected for the examination of the utilization of benzamide, 2-chlorobenzamide and 2,6-dichlorobenzamide. All the strains proved to utilize benzamide as carbon source independently of the presence of soil extract. The growth (turbidity) was directly dependent on the concentration of benzamide when $\mathrm{NH}_{4} \mathrm{NO}_{3}$ was used as nitrogen source (Fig. 7).

These Artbrobacter strains could also utilize benzamide as the sole nitrogen source. 


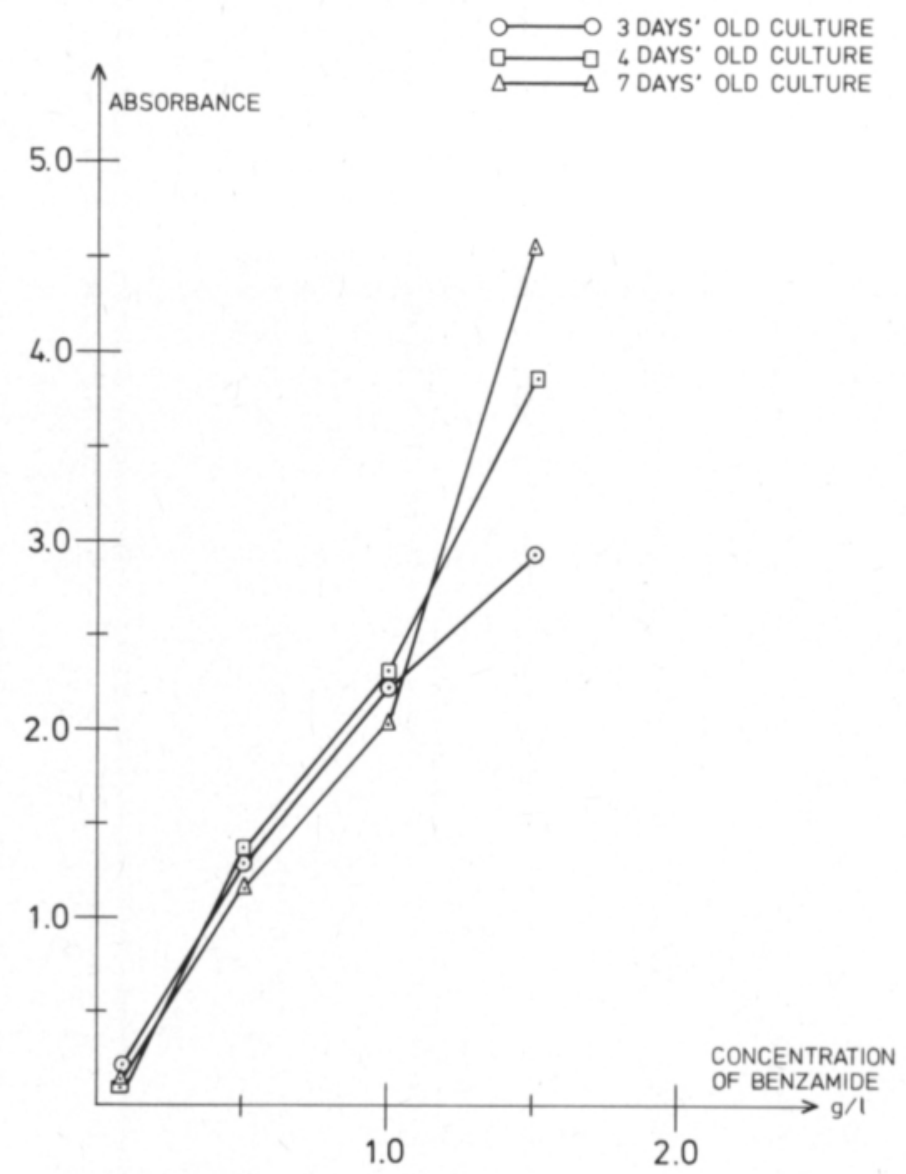

Fig. 7. Dependence of growth upon the concentration of benzamide. Absorbance is the mean absorbance for thirteen Artbrobacter strains, cultivated without soil extract benzamide as energy and carbon source and $\mathrm{NH}_{4} \mathrm{NO}_{3}$ as nitrogen source.

The total degradation of benzamide by Artbrobacter strains could also be seen on the TLC plates under UV-light. After 3-5 weeks this compound could no longer be detected. No growth was detected when 2-chlorobenzamide or 2,6-dichlorobenzamide was used as carbon source instead of benzamide. Even when only half of the benzamide was replaced by 2-chlorobenzamide no increase in the turbidity was observed after seven days.

The utilization of sodium benzoate, 2-chlorobenzoic acid and 2,6-dichlorobenzoic acid was examinated with all twelve strains isolated from medium A. All these strains utilized sodium benzoate as carbon source in the presence of dichlobenil as well as without the soil extract. Ten of them grew better with the soil extract than without it, whereas in two cases the soil extract appeared to have no significant effect on the growth.

The media containing only 2-chlorobenzoic acid or 2,6-dichlorobenzoic acid as carbon source did not produce microbial growth.

The amounts of 2,6-dichlorobenzoic acid were still so high in 6-8 weeks old cultures in medium A that the large, "tailing" spot of 2,6-dichlorobenzoic acid could be seen on TLC plates under UV-light. 


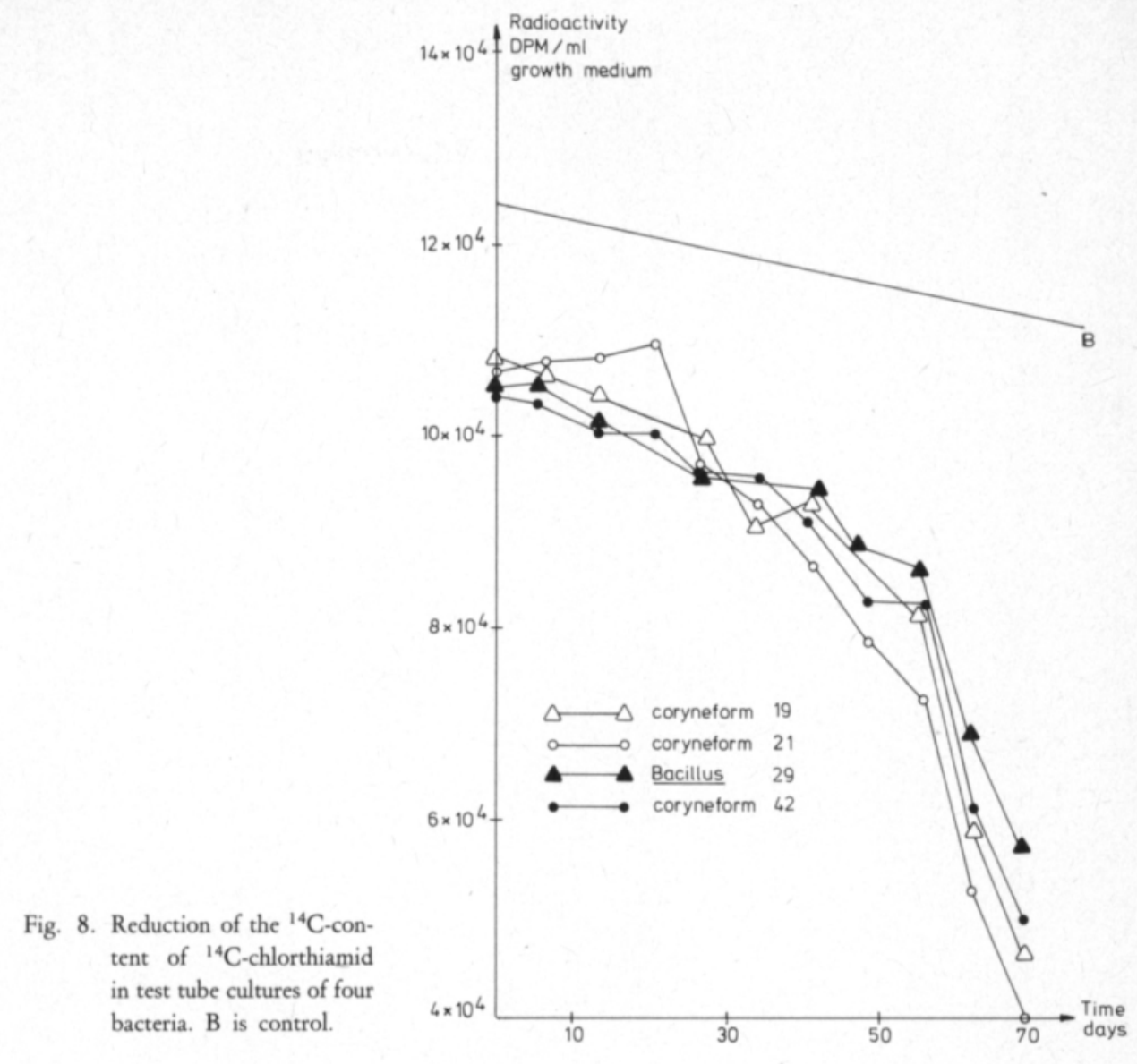

\subsubsection{Microbial ${ }^{14} \mathrm{CO}_{2}$ formation from ${ }^{14} \mathrm{C}$-chlortbiamid}

In the preliminary tests using ${ }^{14} \mathrm{C}$-chlorthiamid in the media the radioactivities of all microbial strains in the tube cultures were measured, using two duplicate measurements, when the growth medium had become turbid (after 3-7 weeks). The radioactive substance liberated from the growth medium was analyzed using $\mathrm{NaOH}$-absorption and found to be ${ }^{14} \mathrm{CO}_{2}$. The best ${ }^{14} \mathrm{CO}_{2}$-producers were three coryneform bacteria 19,21 and 42 and Bacillus 29, all isolated from medium B. These organisms could liberate $40-60 \%$ of ${ }^{14} \mathrm{C}$ from ${ }^{14} \mathrm{C}$-chlorthiamid as ${ }^{14} \mathrm{CO}_{2}$ in 10 weeks (Fig. 8). Other microorganisms liberating ${ }^{14} \mathrm{CO}_{2}$ rather well (approximately $30 \%$ of the theoretical ${ }^{14} \mathrm{C}$ ) in 6-7 weeks were Artbrobacter (3), Bacilli (3) and coryneforms (5). Most of the strains which were found to liberate ${ }^{14} \mathrm{CO}_{2}$ well or rather well grew very poorly in the test medium. Conversely, the Artbrobacter strains growing well in the test medium liberated no or only slightly ${ }^{14} \mathrm{CO}_{2}$ from ${ }^{14} \mathrm{C}$-chlorthiamid during the growth period. Some of them liberated ${ }^{14} \mathrm{CO}_{2}$ (up to $20-30 \%$ of the theoretical ${ }^{14} \mathrm{C}$ ) just after the medium had become turbid, after 5 weeks' incubation. 


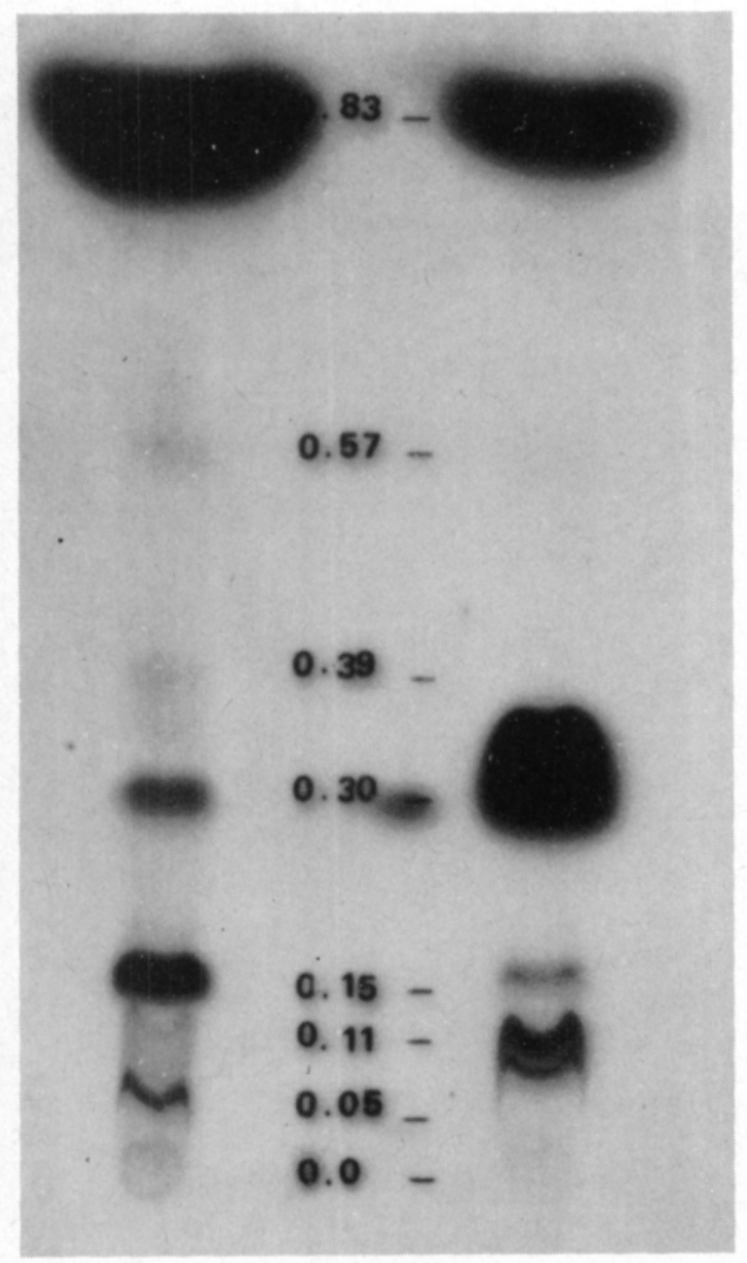

Fig. 9. Autoradiogram of the ether extract of ${ }^{14} \mathrm{C}$-chlorthiamid-containing medium after five weeks' cultivation of Artbrobacter strains 58 (left) and 77 (right). The illumination time of this autoradiogram was four weeks.

\subsubsection{Characterization of metabolites separated by chromatography}

The microorganisms were found by the aid of TLC and autoradiography to produce up to eight radioactive compounds from ${ }^{14} \mathrm{C}$-chlorthiamid during 5 weeks' cultivation in the medium B. In older cultures as many as 10-12 radioactive compounds were found. Usually only the major radioactive compounds (chlorthiamid, dichlobenil, and 2,6-dichlorobenzamide) were found in the autoradiograms. The strains isolated and grown in the medium A produced only the major metabolites. The autoradiograms of ether extracts $\mathrm{pH}<2$ after five weeks' cultivation of Artbrobacter strains 58 and 77, along with $\mathrm{R}_{\mathrm{f}}$-values, can be seen in Fig. 9. The solvent used was ethanol in toluene $(10 \% \mathrm{w} / \mathrm{w})$. The $\mathrm{R}_{\mathrm{f}}$-values of the spots were not stable, and therefore the characterization had to be effected using chemical methods.

The radioactive compound with an $\mathrm{R}_{\mathrm{f}}$-value of 0.0 was considered tentatively with the aid of UV-illumination of TLC plates to be a humus component. Many ether extracts of microbial media A or B containig soil extract gave a yellow spot with $R_{\mathrm{f}}$-value 0.0 in all the solvent systems used. Under UV-light at $254 \mathrm{~nm}$ the colour was blue and at $366 \mathrm{~nm}$ violet. In the gel-filtration of the radioactive growth 
Fig. 10.Eluation diagram of the compound with $\mathrm{R}_{\mathrm{f}}$-value 0.0 on Sephadex LH-20 in phosphate buffer, pH 7.

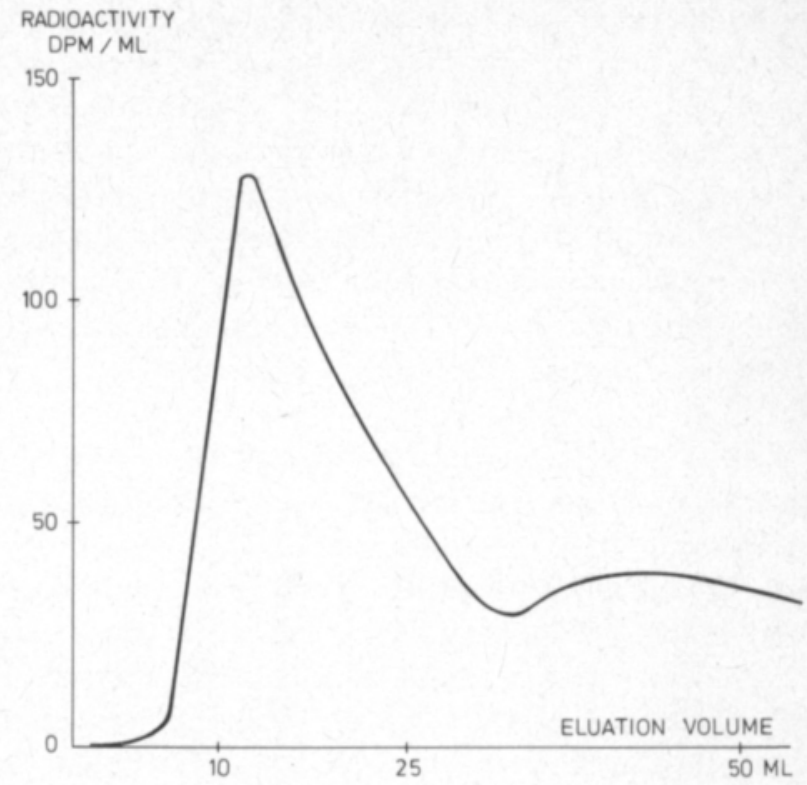

media of Artbrobacter strains 57 and 58 the first fractions of filtrate contained a yellow compound of high molecular weight and very low specific radioactivity. When a TLC of the ether extract of this compound was performed a radioactive spot with $\mathrm{R}_{\mathrm{f}}$-value 0.0 was obtained. Mass-spectral anlysis did not give any clear result for this compound but it seems to have a molecular weight of over 400 and it yields many peaks (many fragments), which could be evidence of a complex molecular structure. In TLC, Folin-Ciocalteu reagent gave a positive result at $\mathrm{R}_{\mathrm{f}}$ value 0.0 , indicating that this compound has one or more aromatic rings.

The compound with an $R_{f}$-value of 0.05 in the solvent ethanol in toluene was found very occasionally and was not identical with any of the reference compounds used. Folin-Ciocalteu reagent gave a positive result at $R_{f}$-value 0.05 . The amount of this compound was very low according to the radioactivity measurements - only less than $5 \%$ of the total radioactivity was found at this $\mathrm{R}_{\mathrm{f}}$-value.

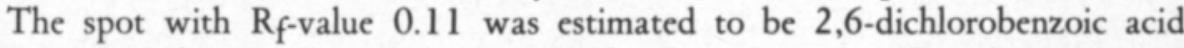
because it had the same $R_{\mathrm{f}}$-value as 2,6-dichlorobenzoic acid in the solvent systems ethanol in toluene ( 10 and $5 \% \mathrm{w} / \mathrm{w})$ and acetone in hexane $20 \% \mathrm{w} / \mathrm{w}\left(\mathrm{R}_{\mathrm{f}}\right.$-value 0.08 ). This compound and 2,6-dichlorobenzoic acid both cochromatographed in 10 $\% \mathrm{w} / \mathrm{w}$ ethanol in benzene $\left(\mathrm{R}_{\mathrm{f}}\right.$-value 0.03$), 5 \% \mathrm{w} / \mathrm{w}$ ethanol in benzene $\left(\mathrm{R}_{\mathrm{f}}\right.$-value $0.05)$ and in chloroform $\left(\mathrm{R}_{\mathrm{f}}\right.$-value 0.01$)$. Folin-Ciocalteu reagent gave a positive result. The amount of this compound was always rather low (only $<1 \%$ of the radioactivity). This compound was found in most microbial growth solutions $\mathrm{A}$ and in also some growth solutions B.

The compound with $\mathrm{R}_{\mathrm{f}}$-value 0.15 was not observed very frequently. In the TLC purification it divided into two spots, the smaller being an original one and the larger a new one. The new spot had the same $R_{f}$-value as dichlobenil and could be cochromatographed with dichlobenil. The mass-spectral analysis gave only the massspectra of dichlobenil.

The compound with $\mathrm{R}_{\mathrm{f}}$-value 0.30 in the solvent ethanol in toluene $10 \% \mathrm{w} / \mathrm{w}$ 
was found in most of the chromatograms. Its amount was so high that even FolinCiocalteu reagent and silver nitrate-2-phenoxyethanol gave positive results. This compound was identified as 2,6-dichlorobenzamide with the aid of cochromatography using the solvents ethanol in toluene (20 and $10 \% \mathrm{w} / \mathrm{w})$, ethanol in benzene ( $5 \% \mathrm{w} / \mathrm{w})$ and chloroform. The $\mathrm{R}_{\mathrm{f}}$-values were in these systems $0.50,0.30,0.23$ and 0.10 respectively. This compound also had the same $R_{f}$-value as 2,6-dichlorobenzamide in the other TLC systems used. The amount of this compound could be even $30 \%$ of the total radioactivity found by TLC. A small amout of 2,6-dichlorobenzamide was found in the ether extract of the uninoculated medium.

The compound with $R_{f}$-value of 0.39 was found in a very few ether extracts of microbial cultures. The amount of it was very small $(<1 \%)$. It was clearly different from all the reference compounds used because of the different $R_{\mathrm{f}}$-value.

The compound with $R_{f}$-value 0.57 in the solvent ethanol in toluene was found only in small amounts in a few cultures of 3 weeks. This compound was identified as the starting substance, chlorthiamid. The amount of this compound was high in uninoculated or young cultures, but during incubation it was degraded to the other products. In cochromatography this compound and radioactive chlorthiamid cochromatographed to an $\mathrm{R}_{\mathrm{f}}$-value of 0.67 in the solvent ethanol in benzene (5\% $\mathrm{w} / \mathrm{w}$ ), and to the $\mathrm{R}_{\mathrm{f}}$-value $0.55-0.57$ in the solvent ethanol in toluene ( 10 and 20 $\% \mathrm{w} / \mathrm{w})$.

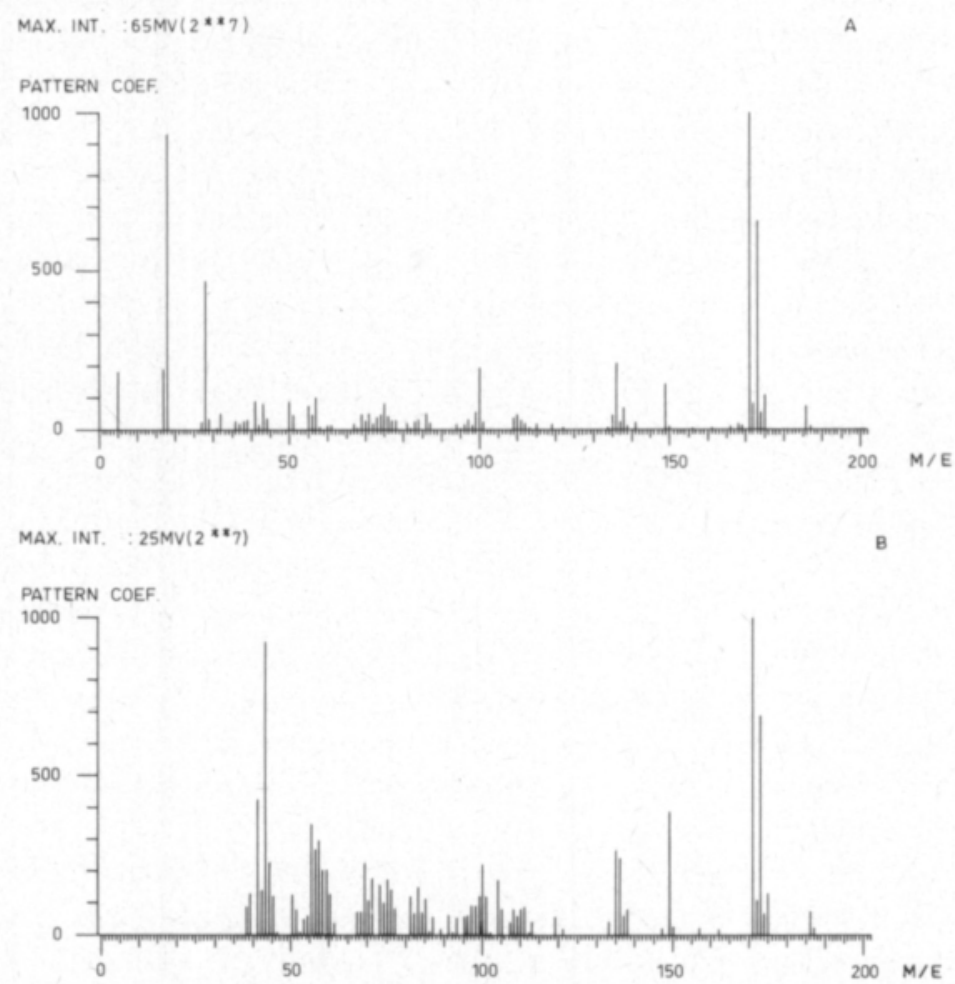

Fig. 11. The mass spectra of a mixture of the compound with $R_{f}$ value 0.83 and the degradation product of the compound with $\mathrm{R}_{\mathrm{f}}$-value 0.15 (A), and the mass spectra of Fluka dichlobenil (B). 
The compound with $\mathrm{R}_{\mathrm{f}}$-value 0.83 was found in almost all chromatograms. The amount of it in young cultures was so high that this compound gave a positive result on the TLC plate with silver nitrate-2-phenoxyethanol and sometimes also with Folin-Ciocalteu reagent. In $8-9$ weeks old cultures this compound was no longer detected. This compound was also found in uninoculated medium. It gave one spot with standard dichlobenil in cochromatography, with $\mathrm{R}_{\mathrm{f}}$-values of 0.81 in the solvent ethanol in benzene ( $5 \% \mathrm{w} / \mathrm{w}), 0.83$ in ethanol in toluene $(10 \% \mathrm{w} / \mathrm{w})$ and 0.39 in chloroform. In the mass-spectral analysis the mixture of this compound and the degradation product of the spot with $R_{\mathrm{f}}$-value 0.15 gave the mass-spectra of dichlobenil (Fig. 11).

In gas-chromatographic analyses the ether extracts of $\mathrm{pH} 11$ of five weeks old cultures of Artbrobacter strains 57, 58 and 59 contained dichlobenil. Retention time was $6.7 \mathrm{~min}$ at $154^{\circ} \mathrm{C}$. The amount of dichlobenil was $10 \mathrm{mg}$ for $1000 \mathrm{ml}$ of growth medium. It means that $20 \%$ of dichlobenil added still remained after five weeks.

In some TLC plates of old cultures of Artbrobacter there were two or three more compounds. The amounts of these were very small (only $0.5 \%$ of the total radioactivity). None of them were identified, but one had an $R_{f}$-value of 0.25 in the solvent ethanol in toluene $(10 \% \mathrm{w} / \mathrm{w})$, which is very close to that of 2 -chlorobenzoic acid $(0.27)$ in the same plates.

No 1,3-dichlorobenzene or 2,6-dichlorophenol was found in gas-chromatographic analyses of the ether extracts $(\mathrm{pH} 10-11)$ of Artbrobacter cultures using dichlobenil as cosubstrate in medium B. 2-Chlorobenzoic acid was not detected using a mass-spectrometer equipped with a gas chromatograph.

The degradation of ${ }^{14} \mathrm{C}$-ring labelled 2,6-dichlorobenzoic acid could be studied in only a few cultures of the seven Artbrobacter strains with good growth in medium $\mathrm{B}$ and liberating high amounts of chloride from dichlobenil (Section 3.3.6.) and also in the cultures of the Bacillus 29 and those of three coryneforms 19, 21 and 42 liberating ${ }^{14} \mathrm{CO}_{2}$ well from ${ }^{14} \mathrm{C}$-carbonyl labelled chlorthiamid (Section 3.3.3.).

The main part of the radioactivity was extracted with diethyl ether at $\mathrm{pH} 1$. The acid compounds were extracted at this $\mathrm{pH}$ with the recovery of $65-90 \%$ of the total radioactivity. Less than $1 \%$ of the radioactivity was detected in the ether extract at $\mathrm{pH} 4-5$ using the scintillation counter, while the extract at $\mathrm{pH} 11$ and the non-extracted part were not radioactive. The Artbrobacter strains tested produced only one, small metabolite from 2,6-dichlorobenzoic acid, while the other coryneforms 19, 21 and 42 and the Bacillus 29 produced three or four. These metabolites and their $\mathrm{R}_{\mathrm{f}}$-values in chloroform-ethanol-acetic acid $(89+10+1)$ are presented in Fig. 12.

The largest and darkest radioactive spot, with $R_{f}$-value $0.11-0.34$, was the starting compound, 2,6-dichlorobenzoic acid. This spot contained more than $99 \%$ of the total radioactivity found. It is possible that another metabolite with the same $\mathrm{R}_{\mathrm{f}}$-value was covered by the strong spot.

The amount of all the metabolites was very low even after an incubation time of 62 days at $26^{\circ} \mathrm{C}$ on the gyrotory shaker at $175 \mathrm{rpm}$. During the incubation two coryneforms which produced three or four metabolites of ring-labelled 2,6-dichlorobenzoic acid were contaminated with Aspergillus. The metabolites in the contaminated and non-contaminated cultures were the same. The carbon source, benzamide, was, however, completely used up in the contaminated cultures. The 


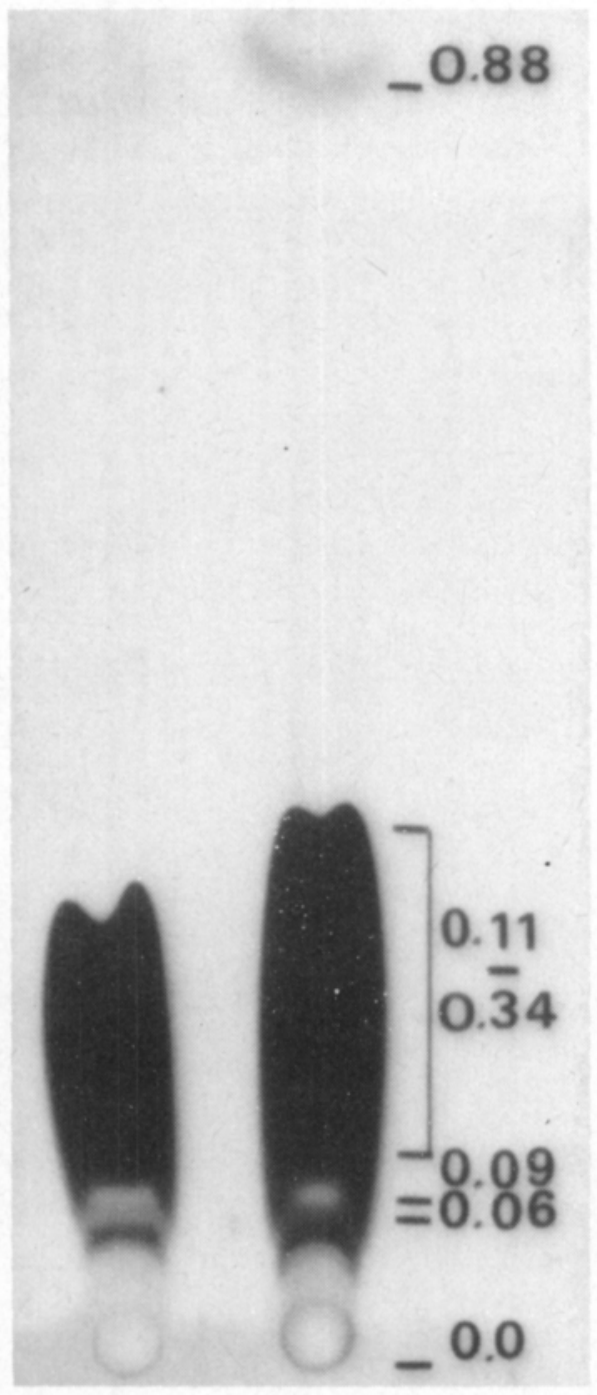

Fig. 12. Autoradiogram of the ether extract of ${ }^{14} \mathrm{C}$-ring labelled 2,6-dichlorobenzoic acidcontaining medium after nine weeks' cultivation of Bacillus 29 (left) and coryneform 21 (right). The illumination time of this autoradiogram was five weeks.

amount of ${ }^{14} \mathrm{C}$-ring labelled 2,6-dichlorobenzoic acid was available in so limited amounts that this cultivation could not be repeated.

Judging from its behaviour in UV-light at $254 \mathrm{~nm}$ and $366 \mathrm{~nm}$, the metabolite with an $R_{f}$-value of 0 may be a humus component originated from soil extract.

The metabolite with $R_{f}$-value of 0.06 was found also in the ether extract of the cultures of some Artbrobacter.

In the TLC purification on the metabolite with $R_{f}$-value 0.88 (see Fig. 12) was separated in two spots: to one degradation product and to the original one. The degradation product had the same $R_{\mathrm{f}}$-value as the metabolite with $\mathrm{R}_{\mathrm{f}}$-value 0.09 in the solvent chloroform-ethanol-acetic acid $(89+10+1)$.

None of these metabolites found by autoradiographic technique were either benzoic acid, 2-chlorobenzoic acid or 2,6-dichlorophenol, and none could be analyzed by gas chromatography or mass fragmentography because the amounts of the compounds were so small. 


\subsubsection{Ability of microorganisms to produce ammonia from 2,6-dicblorobenzamide.}

Arthrobacteria, bacilli and unidentified coryneforms, thirty-five strains in all were selected for the 2,6-dichlorobenzamide amidase test. After one day's incubation a clear positive reaction was observed for 18 microbial strains, 13 strains gave a weakly positive result and the others were negative. After three days 27 bacteria were found to have produced considerable amounts of ammonia from 2,6-dichlorobenzamide. Weak ammonia production was observed for 6 of the strains, while two failed completely to produce measurable amounts of ammonia.

The Artbrobacter strains exhibiting good growth in the medium B seemed to be the most active producers of ammonia from 2,6-dichlorobenzamide.

\subsubsection{The dechlorination of dichlobenil and related compounds}

Ten of the bacterial strains tested had a clear capacity to dechlorinate dichlobenil aerobically, two could dechlorinate this substrate only weakly and 25 strains did not liberate any $\mathrm{Cl}^{-}$to their growth medium from dichlobenil. All bacteria dechlorinating dichlobenil belonged to the genus Artbrobacter. These grew well in the test medium, although all the strains growing well in the test medium did not liberate chloride.

Chloride liberations from dichlobenil and related compounds are presented in Table 4.

The dechlorination of dichlobenil did not begin until after a few days, when the shake culture had become turbid. After 21 days the growth of the bacteria tested entered the stationary phase and in this time the most effective strains liberated more than half of the theoretical chlorine content of dichlobenil. No more chloride was liberated after a further 7 or 14 days' incubation.

In anaerobic cultivation the strains produced no chloride ion from dichlobenil in 21 days.

The same bacteria were also found to have a slight capacity of liberating chloride from 2,6-dichlorobenzamide and 2,6-dichlorobenzoic acid, and to a lesser extent from 1,3-dichlorobenzene or 2,6-dichlorophenol.

Table 4. The chloride ion liberation of dichlobenil and some related compounds by Artbrobacter strains. The numbers indicate the per cents of the theoretical chloride liberation after 21 days' incubation time (mean and standard deviation).

\begin{tabular}{llllll}
\hline Strain & \multicolumn{2}{l}{ Dechlorinating } & compound & & \\
\cline { 2 - 6 } & Dichlobenil & $\begin{array}{l}\text { 2,6-Dichloro- } \\
\text { benzamide }\end{array}$ & $\begin{array}{l}\text { 2,6-Dichloro- } \\
\text { benzoic acid }\end{array}$ & $\begin{array}{l}\text { 1,3-Dichloro- } \\
\text { benzene }\end{array}$ & $\begin{array}{l}\text { 2,6-Dichloro- } \\
\text { phenol }\end{array}$ \\
\hline 52 & $52 \pm 36$ & $52 \pm 9$ & $27 \pm 10$ & $18 \pm 4$ & none \\
53 & $89 \pm 14$ & $34 \pm 8$ & $27 \pm 6$ & $27 \pm 6$ & $10 \pm 2$ \\
54 & $53 \pm 22$ & $32 \pm 13$ & $21 \pm 15$ & $18 \pm 4$ & none \\
55 & $83 \pm 22$ & $32 \pm 8$ & $33 \pm 13$ & $15 \pm 4$ & none \\
56 & $71 \pm 7$ & $32 \pm 11$ & $33 \pm 6$ & $21 \pm 4$ & $41 \pm 8$ \\
57 & $79 \pm 21$ & $23 \pm 6$ & $33 \pm 15$ & $15 \pm 12$ & $22 \pm 5$ \\
58 & $52 \pm 9$ & $36 \pm 9$ & $38 \pm 12$ & $24 \pm 4$ & $25 \pm 7$ \\
70 & $62 \pm 12$ & $25 \pm 13$ & $33 \pm 8$ & $25 \pm 12$ & none \\
76 & $57 \pm 12$ & $23 \pm 13$ & $27 \pm 8$ & $22 \pm 3$ & none \\
77 & $57 \pm 17$ & $23 \pm 4$ & $33 \pm 8$ & $27 \pm 7$ & none \\
\hline 5
\end{tabular}


The bacteria capable of decarboxylating ${ }^{14} \mathrm{CO}_{2}$ from ${ }^{14} \mathrm{C}$-carbonyl-labelled chlorthiamid did not liberate any chlorine as inorganic chloride from dichlobenil or 2,6-dichlorophenol.

\subsubsection{Cleavage of the aromatic ring of benzamide derivatives}

Nineteen bacterial strains growing well in medium B were selected for the Warburg manometric test. Fourteen of these, all belonging to the genus Artbrobacter, were clearly capable of cleaving the aromatic ring. These strains required oxygen during an incubation time of 4-4.5 h when benzamide was used as substrate. Oxygen requirement was $3.9-7.2 \mu \mathrm{mol}$ oxygen for $3.3 \mu \mathrm{mol}$ benzamide. The magnitude of the oxygen consumption was strain-dependent. The reaction had not terminated when the experiment was finnished.

The strain Artbrobacter 56 consumed oxygen in some tests when 2,6-dichlorobenzamide was used as substrate. For $2.1 \mu \mathrm{mol}$ 2,6-dichlorobenzamide the oxygen demand was $0,6 \mu \mathrm{mol}$ in 4 hours. This strain did not consume any oxygen for substrate degradation when 2-chlorobenzamide, 2,6-dichloro-3-hydroxybenzamide, 2,6-dichloro-4-hydroxybenzamide or 2,6-dichlorophenol were used as substrates.

The presence of dichlobenil in the substrate solution had no effect on oxygen consumption.

The ring cleavage mechanisms for some phenolic compounds and the catechol production from benzoic acids by the Artbrobacter found to demand oxygen for benzamide metabolism are summarized in Table 5.

In the catechol colour test using 2-chlorobenzoic acid as substrate only Artbrobacter 57 which had a very good capacity for dechlorination, gave a positive result after the reinoculation. The incubation time was 19 days.

The catechol test with 2,6-dichlorobenzoic acid gave a negative result for all the Artbrobacter strains tested.

Table 5. The ring cleavage mechanisms of the degradation of some aromatic compounds and the catechol production of benzoic acids by Artbrobacter strains requiring oxygen in the Warburg manometer test for benzamide degradation.

$\mathrm{DHB}=3$,4-Dihydroxybenzoic acid, $\mathrm{SA}=$ salicylic acid, $\mathrm{CC}=3$-chlorocatechol, $\mathrm{BA}=$ benzoic acid, $\mathrm{CA}=2$-chlorobenzoic acid, DBA $=2,6$-dichlorobenzoic acid, n.t. $=$ not tested, br. $=$ brown

\begin{tabular}{cllllll}
\hline Artbrobacter & \multicolumn{2}{l}{ Ring cleavage mechanism } & \multicolumn{3}{c}{ Catechol production } \\
\cline { 2 - 7 } sp. & DHB & SA & CC & BA & CA & DBA \\
\hline 31 & ortho & meta + ortho & n.t. & n.t. & n.t. & n.t. \\
52 & n.t. & meta & meta & + & - & - \\
53 & ortho & meta & meta & + & - & - \\
54 & br. & br. & meta & - & - & - \\
55 & ortho & n.t. & meta & + & - & - \\
56 & ortho & meta + ortho & meta & + & - & - \\
57 & br. & meta + ortho & meta & - & + & - \\
58 & n.t. & meta + ortho & meta & + & - & - \\
61 & n.t. & meta + ortho & n.t. & - & - & - \\
70 & n.t. & meta & meta & + & - & - \\
71 & n.t. & meta & n.t. & n.t. & n.t. & n.t. \\
73 & ortho & meta & n.t. & n.t. & n.t. & n.t. \\
76 & ortho & meta & meta & + & - & - \\
77 & ortho & meta & meta & + & - & - \\
\hline
\end{tabular}




\subsection{Discussion of the degradation of chlorthiamid and dichlobenil}

The autoradiographic method for isolation of microorganisms serves as a suitable method of isolation those microbes which either cometabolize the pesticide under investigation or at least tolerate high concentrations of the pesticide. It may be that the microorganisms truly absorb the pesticide of the medium but the other possibility is that they produce an extracellular organic solvent which accumulates the pesticide or its degradation product in a solid medium.

None of the microorganisms isolated could use 2,6-dichlorobenzoic acid or its derivatives as carbon or nitrogen source.

The microbial strains isolated from medium A $(1 \mathrm{~g} \mathrm{2,6-dichlorobenzoic} \mathrm{acid} \mathrm{in}$ 11 medium) utilize soil extract as carbon source, and they could only tolerate up to 2 $\mathrm{g} / \mathrm{l}$ of 2,6-dichlorobenzoic acid or 2-chlorobenzoic acid.

In all cases the degradation was cometabolic and the true carbon source was also necessary. In the metabolism tests benzamide served as the sole carbon and nitrogen source for all the microorganism tested. The degradation process was slow and many metabolites accumulated.

In the literature ortho-halogenated aromatic compounds have been reported to serve as carbon source only very occasionally (MILNE et al. 1968, FOURNIER and CATROUX 1972). CHU and KIRSCH (1973) found pentachlorophenol, 2,3,4,6-tetrachlorophenol and 2,4,6-trichlorophenol, but not 2,4-dichlorophenol, 2,6-dichlorophenol or 2-chlorophenol, to serve as carbon source for a bacterial isolate. CRAWFORD et al. (1973), HAIDER et al. (1974), RUISINGER et al. (1976), KNACKMUSS and HELWEG (1978), REINICKE and KNACKMUSS (1978), TAYLOR et al. (1979) and HARTMANN et al. (1979) showed that neither 2-chlorobenzoic acid nor 2-cholorophenol served as carbon source for microorganisms, being degraded only by cometabolism.

It was interesting to note that part of the radioactivity of carbonyl-labelled chlorthiamid and ring-labelled 2,6-dichlorobenzoic acid was bound to soil humus (Figures 9, 10 and 12). There are no prior references in the literature about the binding of dichlobenil or chlorthiamid on humus, but BARTHA (1980) reported that diquat, propanil, parathion, 2,4-D and DDT are bound reversibly to humus. In practice this could mean that a pesticide which has "disappeared" from the soil on the basis of residue analysis is in fact at least in part bound to humus, from where it could be gradually released by mineralizing soil microorganisms.

This binding of chlorthiamid to humus could explain why the recovery of chlorthiamid from peat soil in the work of BEYNON and WRIGHT (1968 a) was only $85 \%$, while they reported recoveries of $92 \%$ for clay and $93 \%$ for sand soil.

A polymerization of aromatic compounds like pesticides may precede the binding of soil humus (HAIDER et al. 1975). The brown colour formed in Rothera tests (Table 5) could be caused by polymerization of aromatic compounds.

A schematic degradation pathway of chlorthiamid and dichlobenil is presented in Fig. 13. It is similar to that presented by FOURNIER $(1974,1975)$ and NIMMO and VERLOOP (1975).

The degradation pathway chlorthiamid $\rightarrow$ dichlobenil $\rightarrow$ 2,6-dichlorobenzamide $\rightarrow$ 2,6-dichlorobenzoic acid may be the same for all the microorganisms isolated. The last step of this pathway must be extremely slow and unimportant, especially for the Artbrobacter strains which had a strong capacity for 


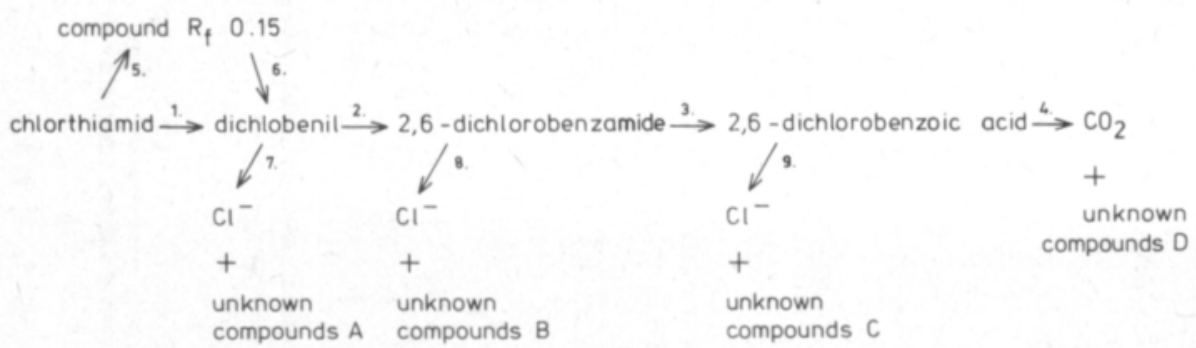

Fig. 13. The degradation schema of the herbicides chlorthiamid and dichlobenil by some Artbrobacter, some other coryneforms and Bacillus.

dechlorination of dichlobenil and 2,6-dichlorobenzamide, because only very low amounts of ${ }^{14} \mathrm{C}$-2,6-dichlorobenzoic acid were formed from ${ }^{14} \mathrm{C}$-chlorthiamid. However, the 2,6-dichlorobenzoic acid formed could not have degraded, because when ${ }^{14} \mathrm{C}$-labelled 2,6-dichlorobenzoic acid was added to the medium the dechlorinating bacteria produced in three weeks only one radioactive metabolite, in an amount representing less than $1 \%$ of the total radioactivity.

NIMMO and VERLOOP (1975) reported that 2,6-dichlorobenzoic acid was formed very slowly from 2,6-dichlorobenzamide and the acid decarboxylated more rapidly to carbon dioxide and other products. The slow formation of 2,6-dichlorobenzoic acid as found in the present work or the rapid degradation of 2,6-dichlorobenzoic acid as reported by NIMMO and VERLOOP (1975) could be the reasons why many workers have found only very small amounts of 2,6-dichlorobenzoic acid or none at all, as in the work of BEYNON and WRIGHT (1968 a), BRIGGS and DAWSON (1970), VERLOOP and NIMMO (1970), MIYAZAKI et al. (1975) and the present work. Only PATE and FUNDERBURK (1966) reported finding 2,6-dichlorobenzoic acid as the only degradation product of dichlobenil. As these investigators cultivated fungi in the rich Czapek nutrient medium containing only $2-3 \mathrm{mg} / \mathrm{l}$ dichlobenil, it is difficult to believe that fungi degrade dichlobenil to 2,6-dichlorobenzoic acid as the only end-product. More probable is that the organic acids formed from sucrose of the medium hydrolysed 2,6-dichlorobenzamide to 2,6-dichlorobenzoic acid when PATE and FUNDERBURK (1966) evaporated hexane extracts (boiling point $69^{\circ} \mathrm{C}$ ). The hydrolysis of amides to the corresponding carboxylic acids is described by ROBERTS et al. (1972) and BROWN (1975) in their chemistry books. In the classic work of REICH et al. (1917) treatment for three hours at $150^{\circ} \mathrm{C}$ with sulphuric acid transformed all dichlobenil to 2,6-dichlorobenzoic acid.

The degradation of chlorthiamid to dichlobenil is a chemical process because dichlobenil could be found also in uninoculated media.

One intermediate product was found in this work between chlorthiamid and dichlobenil. In Fig. 13 this compound has been named as "compound $R_{f} 0.15$ ". It is possible that this is the same compound - a persulphonic acid - as that reported by RAJASEKHARAN PILLAI (1977).

The degradation of dichlobenil to 2,6-dichlorobenzamide occurred in small amounts in the present work even in uninoculated sterile media, although more 2,6-dichlorobenzamide was found in inoculated shake cultures. The degradation may thus also be non-biological, as suggested by BRIGGS and DAWSON (1970). 
The amidase activity against 2,6-dichlorobenzamide appeared to be rather common in the bacteria isolated in the present work. These bacteria must have an amidase enzyme for benzamide because all the organisms could utilize benzamide as the sole nitrogen source. This enzyme has the same function as EC 3. 5.1.4. (ENZYME NOMENCLATURE 1978).

On the basis of their dechlorination and decarboxylation capacities the microorganisms isolated belonged metabolically to two different groups.

The first group included some coryneforms, bacilli and a few arthrobacteria which could decarboxylate 2,6-dichlorobenzoic acid. Three coryneforms and one Bacillus produced at least four metabolites from ring-labelled 2,6-dichlorobenzoic acid. One of these metabolites was identified very tentatively as 1,3-dichlorobenzene, but this could only be verified if more ring-labelled 2,6-dichlorobenzoic acid had been available. These bacteria could liberate as much as approximately half of the radioactivity of the ${ }^{14} \mathrm{C}$-chlorthiamid as ${ }^{14} \mathrm{CO}_{2}$ in 10 weeks. The degradation of these test-tube liquid cultures was approximately 30 times faster than in the soil experiment of FOURNIER $(1974,1975)$. The coryneforms and the Bacillus showed only very poor growth in all the laboratory tests. These bacteria did not dechlorinate dichlobenil or 2,6-dichlorophenol in 21 days.

The other group included some of the Artbrobacter strains isolated. These strains dechlorinated cometabolically dichlobenil, 2,6-dichlorobenzamide and 2,6-dichlorobenzoic acid and to some extent 1,3-dichlorobenzene, while four strains also dechlorinated 2,6-dichlorophenol. The dechlorination enzymes seemed to be rather unspecific.

This dechlorination of dichlobenil and 2,6-dichlorobenzamide was relatively rapid. In 21 days' incubation time in laboratory conditions even $90 \%$ of chlorine of dichlobenil was liberated. This dechlorination capacity must be very important for the total degradation of dichlobenil. After the dechlorination the non-chlorinated hydrocarbon skeleton could be degraded more easily than the original dichlobenil.

However, some chloride liberated by Artbrobacter strains could have cloven off from humus of soil extract medium.

It was encouraging to note that the soil extract medium permitted the dechlorination. Thus the same dechlorination would happen in nature, too.

These Artbrobacter strains could produce up to twelve metabolites from ${ }^{14} \mathrm{C}$-carbonyl labelled chlorthiamid. They also had a good capacity to cleave the aromatic ring. Dichlobenil which was present in the medium did not disturb this ring cleavage. However, these strains did not produce ${ }^{14} \mathrm{CO}_{2}$ from ${ }^{14} \mathrm{C}$-carbonyl labelled chlorthiamid, or if they did the production was very slight and began only after the stationary phase. Some of these Artbrobacter strains produced one metabolite from ${ }^{14} \mathrm{C}$-ring labelled 2,6-dichlorobenzoic acid in a medium containing $\mathrm{NaCl}$.

In the literature there are reports on the photochemical dechlorination of dichlobenil (PLIMMER and HUMMER 1968, PLIMMER 1970, GÄB et al. 1978), but no reports on microbial dechlorination are known by this author. Dichlobenil dechlorinated photochemically in methanol by a reductive mechanism yielding 2-chlorophenyl cyanide and a small amount of phenylcyanide (PLIMMER and HUMMER 1968, PLIMMER 1970). However, 2-chlorobenzoic acid in water yielded 2-hydroxybenzoic acid by hydrolytic and benzoic acid by reductive dechlorination when illuminated (CROSBY and LEITIS 1969).

If the dechlorination occurs before the ring fission it may take place either by re- 
ductive or hydrolytic mechanisms. The reductive dechlorination would be anaerobic (JANKE and FRITSCHE 1978). The present author doesn't know about any reports in the literature on the microbial reductive dechlorination of chlorine joined to the particular aromatic ring.

In hydrolytic dechlorination the chlorine is substituted by a hydroxyl group. MACRAE et al. (1963) observed this type of dechlorination of 2,6-dichlorophenol by Flavobacterium and HORVATH (1971) reported hydrolytic, cometabolic dechlorination of 2,3,6-trichlorobenzoic acid by Brevibacterium. 3-Chlorobenzoic acid is dechlorinated hydrolytically by Pseudomonas (JOHNSTON et al. 1972) and 4-chlorobenzoic acid by Artbrobacter (RUISINGER et a. 1976) and by Nocardia (KLAGES and LINGENS 1979).

If the aromatic ring cleaves first the mechanism of ring cleavage could resemble that presented by SHEPHERD and VILLANUEVA (1959), WHEELES et al. (1967), JAMALUDDIN et al. (1970) and TAYLOR (1970). In all these cases the microorganisms metabolized benzoic acid aerobically, first to either 3-hydroxybenzoic acid or 4-hydroxybenzoic acid and subsequently to 3,4-dihydroxybenzoic acid, which was then easily degraded by ring cleavage. Even the Artbrobacter strains tested cleaved the aromatic ring of 3,4-dihydroxybenzoic acid by the ortbo cleavage mechanism. It would be useful to study the possible ring cleavage and dechlorination of 2,6-dichloro-3,4-dihydroxybenzoic acid by these Artbrobacter strains. BEYNON and WRIGHT (1968 a) did not find any 2,6-dichloro-3-hydroxybenzoic acid in soil as a microbial degradation product of chlorthiamid. Possibly this compound was not in fact formed, or its amount in soil may have been too small to be detected. The finding of 2,6-dichloro-3hydroxybenzoic acid, 2,6-dichloro-4-hydroxybenzoic acid or 2,6-dichloro-3,4dihydroxybenzoic acid in the growth medium of the Artbrobacter strains would solve the question of the degradation pathway of 2,6-dichlorobenzoic acid.

The finding of a catechol compound as an intermediate metabolite in the medium containing originally 2-chlorobenzoic acid during the cultivation of Artbrobacter 57 could indicate either the hydrolytic dechlorination mechanism followed by the formation of 3-chlorocatechol or else by the formation of a 2,6-dichloro-3,4dihydroxyphenolic compound which could then degrade by ring cleavage followed by dechlorination. Furthermore, failure to detect catechols does not necessarily mean that these are not formed. Probably they can be found only for a very short time and always in low amounts, because they are microbiologically and chemically highly reactive.

Higher plants and animals metabolize chlorthiamid and dichlobenil, producing aromatic compounds with 2,6-dichloro-3-hydroxy- or 2,6-dichloro-4-hydroxysubstituents (Figures 2 and 3 ).

JANKE and FRITSCHE (1979) found that Pseudomonas putida first opened the aromatic ring of 4-chlorophenol by meta cleavage after which the dechlorination occurred.

The ring cleavage mechanism of the Artbrobacter strains tested was metabolically tangential, which indicates their versatile capacity. Thus, they could degrade aromatic compounds by both ortho- and meta cleavage. It is possible that benzamide in the growth medium induced the ortho cleavage pathway enzymes for the ring cleavage of 3,4-dihydroxybenzoic acid and salicylic acid. On the other hand the salicylic acid and 3-chlorocatechol of the test substrate also induced the meta 
cleavage enzymes during the long incubation time. FEIST and HEGEMAN (1969), STAINIER and ORNSTON (1973), WILLIAMS et al. (1975), RUISINGER et al. (1976) and RAST et al. (1980) showed that some aromatic compounds induced the meta cleavage pathway enzymes while others induced the ortho cleavage enzymes.

However, the Artbrobacter strains had a good capacity to cleave the aromatic ring and to dechlorinate dichlobenil, but the enzymes needed for these reactions are not contemporary. The ring cleavage enzymes (dioxygenases) could open the aromatic ring in less than 24 hours as shown by Rothera tests and benzamide could be used up metabolically in two or three days. The dechlorination was not found to happen until after one or two weeks' incubation.

Some dechlorinating enzymes which liberate chlorine joined to aliphatic carbon atoms are presented in the review articles of BOLLAG (1974), FOY (1975), KAUFMAN and KEARNEY (1976) and HILL (1978). The best known is probably the DDT-dehydrochlorinase (EC 4.5.1.1.) isolated from insects and microorganisms (ENZYME NOMENCLATURE 1978). The other dechlorinating microbial enzymes isolated dechlorinate for instance lindane or aliphatic chlorinated carboxy acids, or aliphatic, chlorine containing degradation products of phenoxy herbicides.

The dechlorinating enzymes which liberate chlorine joined to a carbon atom in an aromatic ring are less known. KAUFMAN (1962) isolated from rat liver a mixed function oxygenase, a pteridine monooxygenase, which could also defluorinate 4-fluorophenylalanine by a hydrolytic mechanism to inorganic fluoride and tyrosine. The main function of this enzyme was to oxygenate L-phenylalanine to L-tyrosine.

The existence of microbial dechlorinating enzymes for the aromatic compounds must be ecologically very important. At least some of the dechlorinating enzymes may have existed in nature for a long time to break down natural aromatic chlorinated compounds such as chlortetracycline, geodin, griseofulvin and griseofulvamine (WOODCOCK 1972). It is possible that the same dechlorinating enzymes could be effective on many chlorinated compounds, including pesticides.

As a rule arthrobacteria seem to have a powerful capacity to liberate chlorine joined in organic compounds. In the literature there are many reports of arthrobacteria liberating chloride ion from different herbicides such as TCA (GEMMEL and JENSEN 1964), dalapon (KEARNEY et al. 1964), MCPA (BOLLAG et a. 1967), 2,4-D (BOLLAG et al. 1968, TIEDJE et al. 1969) and 2,3,6-trichlorobenzoic acid (HORVATH and ALEXANDER 1970).

Usually it is thought that the dechlorination of a synthetic compound implies some detoxification of this compound, and this may be so in most cases. The dechlorinated compounds may be more easily degradable by a wide variety of microorganisms than the original substances. For instance dichlobenil loses its recalcitrant chlorine substitution in the ortho-position by dechlorination. However, the new compound may polymerize and join to soil humus components, which may be still more undegradable or toxic than the original compound. In the present work a few microorganisms produced a compound attaching to humus from ${ }^{14} \mathrm{C}$-ring labelled 2,6-dichlorobenzoic acid and ${ }^{14} \mathrm{C}$-carbonyl labelled chlorthiamid, although in the latter case the radioactivity of humus could have been due in part to ${ }^{14} \mathrm{CO}_{2}$ trapped by some amine groups of humus. The chemical character of the microbial dechlorination products of dichlobenil, and the relationship between dechlorination and ring cleavage should be further studied. 


\section{Conclusions}

The herbicides chlorthiamid and dichlobenil were not found to have any effect on many microorganisms. However, some Streptomyces strains proved to be rather sensitive to dichlobenil. These strains could be used as indicator organisms in a microbiological method for dichlobenil assay. The inhibition of ATPase activity by dichlobenil was found to cause the inhibition of the growth of the Streptomyces strains.

It would be very important to study the effects of dichlobenil on Streptomyces in soil in order to determine whether the herbicides chlorthiamid and dichlobenil inhibit the growth in these condition as well, and whether this possible inhibition has some ecological significance.

The herbicides chlorthiamid and dichlobenil were found to be degradable in the laboratory tests. Instead of true metabolism the degradation takes place by cometabolism. In the present investigation the true carbon source was benzamide.

Many different soil microorganisms play an important role in this degradation. All the degradation processes found in the present work were aerobic. Some bacteria caused chemical transformations of the side chain of herbicide molecules, producing carbon dioxide from the carbon atom outside the ring. These microorganisms produced four metabolites from ring-labelled 2,6-dichlorobenzoic acid. The identification of these minor metabolites was not successfully accomplished.

Some of the Artbrobacter strains isolated were found to be capable of dechlorinating dichlobenil and some related compounds to inorganic chloride and some other products. The effects of carbon source and chloride concentration on the dechlorination should be studied. The same bacteria could also cleave the aromatic ring. The mechanisms of the dechlorination and the ring cleavage were not solved.

Together with the decarboxylation, the dechlorination and the ring cleavage effect total mineralization of the herbicides chlorthiamid and dichlobenil. In the laboratory shake cultures at $28^{\circ} \mathrm{C}$ the Artbrobacter strains could liberate more than half of the theoretical maximum amount of chlorine in three weeks. The half-life times of the decarboxylation in test tube cultures by Bacillus and some coryneforms were near to ten weeks. Even if the same organisms do in fact degrade the herbicides chlorthiamid and dichlobenil in soil as well, the degradation may be much slower under such conditions.

An investigation is required to study the degradation of herbicides chlorthiamid and dichlobenil in mixed cultures, because there are more enzyme systems for metabolic and cometabolic degradation and the degradation could be quicker and more completed than in pure cultures. Also the mixed, versatile microorganims of soil with the aid of natural photolysis might complete the degradation capacity of each others.

\section{REFERENCES}

ANON. 1968. Vesianalyysitoimikunnan mietintō. Komiteamietintö B 19. Helsinki.

- 1979 a. Kasvinsuojeluopas. Torjunta-aineet 1979-80. Berner Osakeyhtiō. 65 p. Helsinki.

- 1979 b. Torjunta-aineet. Kemira. 80 p. Helsinki. 
ARAI, T., OTAKE, M., ENOMOTO, S., GOTO, S. \& KUWAHARA, S. 1970. Determination of Pseudomonas aeruginosa by biochemical test methods. II Acylamidase test, a modified biochemical test for the identification of Pseudomonas aeruginosa. Jap. J. Microbiol. 14: 279-284.

ATLAS, R. M. \& BARTHA, R. 1981. Microbial ecology. Fundamentals and applications 560 p. Reading, Mass.

AUGUSTINSSON, K-B. 1966. Experimentell biokemi. 544 p. Stockholm.

BARTHA, R. 1980. Pesticide residues in humus. ASM News 46: 356-360.

BEYNON, K. I., DAVIES, L. \& ELGAR, K. 1966 a. Analysis of crops and soils for residues of 2,6-dichlorobenzonitrile (dichlobenil) and 2,6-dichlorothiobenzamide (chlorthiamid). II Results. J. Sci. Fd Agric. 17: 156-161.

- DAVIS, L., ELGAR, K. \& WRIGHT, A. N. 1966 b. Analysis of crops and soils for residues of 2,6-dichlorobenzonitrile (dichlobenil) and 2,6-dichlorothiobenzamide (chlorthiamid). I Development of method. J. Sci. Fd Agric. 17: 151-155.

- \& WRIGHT, A. N. 1968 a. Breakdown of the herbicide ${ }^{14}$ C-chlorthiamid. I Laboratory studies of the breakdown in soil. J. Sci. Fd Agric. 19: 723-726.

- \& WRIGHT, A. N. 1968 b. Breakdown of the herbicide ${ }^{14} \mathrm{C}$-chlorthiamid. II Glasshouse studies of breakdown in soils and in crops grown in the soils. J. Sci. Fd Agric. 19: 727-732.

BOLIER, G., MAAS, H. L. \& BOOTSMA, R. van der 1973. The toxicity of the herbicide dichlobenil to goldfish (Carassius auratus). Meded. Fac. Landbouwwetensch. Rijksuniv. Gent 38: 733-740.

BOLlAG, J-M. 1974. Microbial transformation of pesticides. Adv. Appl. Microbiol. 18: 75-1 30.

- , BRIGGS, G. G., DAWSON, J. E. \& ALEXANDER, M. 1968. 2,4-D metabolism. Enzymatic degradation of chlorocatechols. J. Agric. Fd Chem. 16: 829-833.

- , HELLING, C. S. \& ALEXANDER, M. 1967. Metabolism of 4-chloro-2-methylphenoxy acetic acid by soil bacteria. Appl. Microbiol. 15: 1393-1398.

BOOTH, C. 1971. Fungal culture media. Methods in Microbiology 4: 49-94. London.

BOSSEL, H. 1974. Umwelt- und Rückstandsfragen bei der Anwendung vom Herbiziden im Forst. Allg. Forstz. 29: 48-49.

BRIGGS, G. G. \& DAWSON, J. E. 1970. Hydrolysis of 2,6-dichlorobenzonitrile in soils. J. Agric. Fd Chem. 18: 97-99.

BROWN, R. F. 1975. Organic chemistry. 1008 p. Belmont, Calif.

BUCHANAN, R. E. \& GIBBONS, N. E. (ed.) 1974. Bergey's manual of determinative bacteriology. 1246 p. 8 th Ed. Baltimore.

CAMPER, N. D. \& SHIVELY, N. M. 1974. Effects of selected herbicides on bacterial populations in fresh and treated water. 10 p. WRRI, Clemson University. Clemson, S. Ca.

CHU, J. \& KIRSCH, E. J. 1973. Utilization of halophenols by pentachlorophenol metabolizing bacterium. Devel. Ind Microbiol. 14: 264-273.

COPE, O. B., MCCRAREN, J. P. \& LAFAYETTE. E. 1969. Effects of dichlobenil on two fishpond environments. Weed Sci. 17: 158-165.

CRAWFORD, R. L., MCCOY, E., HARKIN, J. M., KIRK, T. K. \& OBST, J. R. 1973. Degradation of methoxylated benzoic acids by a Nocardia from a lignin-rich environment: Significance to lignin degradation and effects of chloro substituents. Appl. Microbiol. 26: 176-184.

CROSBY, D. G. \& LEITIS, E. 1969. Photodecomposition of chlorobenzoic acids. J. Agric. Fd Chem. 17: 1033-1035.

CULLIMORE, D. R. 1971. Interaction between herbicides and soil microorganisms. Residue Rev. 35: 6580.

DAVIS, G. H. G. \& NEWTON, K. G. 1969. Numerical taxonomy of some named coryneform bacteria. J. Gen. Microbiol. 56: 195-214.

DEBONA, A. C. \& AUDUS, L. J. 1970. Studies on the effects of herbicides on soil nitrification. Weed Res. 10: $250-263$.

DEEKEN, J. H. 1974. Chloracne induced by 2,6-dichlorobenzonitrile. Arch. Dermatol. 109: 245-246.

ENZYME NOMENCLATURE 1978. Recommendations of the Nomenclature Committee of the International Union of Biochemistry 606 p. New York.

EVANS, W. C. 1947. Oxidations of phenol and benzoic acid by some soil bacteria. Biochem. J. 41: 373382.

- SMITH, B. S., MOSS, P. \& FERNLEY, H. N. 1971. Bacterial metabolism of 4-chlorophenoxyacetate. Biochem. J. 122: 509-517.

FEIST, C. F. \& HEGEMAN, G. D. 1969. Phenol and benzoate metabolism by Pseudomonas putida: 
regulation of tangential pathways. J. Bact. 100: 869-877.

FELDER, E., TIEPOLO, U. \& MENGASSINI, A. 1973 a. Gas chromatographic analysis of monohalobenzoic acid isomers. J. Chromatog. 82: 390-393.

- , TIEPOLO, U. \& MENGASSINI, A. 1973 b. Method for the esterification of carboxylic acids in gas chromatographic analysis. J. Chromatog. 82: 291-296.

FOURNIER, J-C. 1972. Etude de la dégradation microbienne de la 2,6-dichlorobenzamide: Comparaison avec le metabolisme d'autres benzamides. Proposition d'un schéma d'etude de la biodégradabilité de produits phytosanitaires nouveaux. 129 p. Thése. Ministere de l'education nationale. Conservatoire National des Arts et Metiers. Chaire de biologie. Paris.

- 1974. Degradation microbienne de la 2,6-dichlorobenzamide dans des modeles de laboratoire. I Dégradation de la 2,6-dichlorobenzamide dans le sol, comparaison avec l'évolution d'autres benzamides différemment substituées, recherche des produits du métabolisme. Chemosphere 3: 77-82.

- 1975. Degradation microbienne de la 2,6-dichlorobenzamide dans des modeles de laboratoire. II Influence d'addition de substrats carbonés simples sur la biodégradation de la 2,6-dichlorobenzamide. Chemosphere 4: 35-40.

- \& CATROUX, G. 1972. Etude du métabolisme de la benzamide et de ses dérivés mono et dichlorés par des souches dé Aspergillus sp. C. R. Acad. Sci. Paris 275: 1723-1726.

FOY, C. L. 1975. The chlorinated aliphatic acids. Herbicides 1: 399-452. Ed. P. C. Kearney \& D. D. Kaufman. 2nd Ed. New York.

GÄB, S., PARLAR, H. \& KORTE, F. 1978. A simple method for the determination of the photomineralization rate of pesticides as solids or adsorbed on particulate matter. V-523. 4th Intern. Congr. Pesticide Chem. (IUPAC). Zurich.

GEMMELL, C. G. \& JENSEN, H. L. 1964. Some studies on trichloroacetate decomposing soil bacteria. Arch. Mikrobiol. 48: 386-392.

GILMAN, J. C. 1957. A manual of soil fungi. 450 p. 2nd Ed. Ames, Ia.

GRIFFITHS, M. H., MOSS, J. A., ROSE, J. A. \& HATHWAY, D. E. 1966. The comparative metabolism of 2,6-dichlorothiobenzmide (Prefix) and 2,6-dichlorobenzonitrile in the dog and rat. Biochem. J. 98 : $770-781$.

GROSSBARD, E. 1970. The distribution of ${ }^{14} \mathrm{C}$ labelled simazine and atrazine before and after incubation detected by autoradiography of soil particles. Meded. Fac. Landbowwetensch. Rijkuniv. Gent 35 : $531-542$.

HAIDER, K., JAGNOW, G., KOHNEN, R. \& LIM, A. U. 1974. Abbau chlorierten Benzole, Phenole und Cyclohexan-Derivated durch Benzol und Phenol verwertende Bodenbakterien unter aeroben Bedingungen. Arch. Microbiol. 96: 182-200.

- , MARTIN J. P. \& FILIP, Z. 1975. Humus biochemistry. Soil Biochemistry 4: 195-244. New York.

HARTMANN, J., REINICKE, W. \& KNACKMUSS, H-J. 1979. Metabolism of 3-chloro-, 4-chloro-, and 3,5-dichlorobenzoate by a pseudomonad. Appl. Environ. Microbiol. 37: 421-428.

HEINONEN, H. 1976. The effect of herbicide dichlobenil to some Streptomyces. Acta Agric. Scand. 26: 277281.

HELWEG, A. 1972. Chlorthiamids bestandighed i jord. II Chlorthiamid og dichlobenils indflydelse på $\mathrm{CO}_{2}$ udskillelse, ammonifikation og nitrifikation $\mathrm{i}$ jord. Tidsskr. Pl. avl. 76: 145-155.

HERZEL, F. 1980. Zur Rückstandsbestimmung von 2,6-Dichlorobenzonitrile aus Boden und Wasser. J. Chromatogr. 193: 320-321.

HILL, I. R. 1978. Microbial transformation of pesticides. Pesticide Microbiology p. 137-202. London. HILTUNEN, T. PESSALA, B. \& RYTSÄ, E. 1979. Torjunta-aineet. 68 p. Kasvinsuojeluseura ry. Helsinki.

HOGETSU, T., SHIBAOKA, H. \& SHIMOKORIYMA, M. 1974. Involvement of cellulose synthesis in actions of gibberellin and kinetin on cell expansion. 2,6-Dichlorobenzonitrile as a new cellulose-synthesis inhibitor. Plant and Cell Physiol. 15: 389-393.

HOLDER, A. J. \& COLLEE, J. G. 1971. I Routine biochemical tests. Methods in Microbiology 6 A: 2-32. London.

HORVATH, R. S. 1971. Cometabolism of herbicide 2,3,6-trichlorobenzoate. J. Agric. Fd Chem. 19: 291293.

- 1972. Cometabolism of the herbicide 2,3,6-trichlorobenzoate by natural microbial populations. Bull. Environ. Contam. Toxicol. 7: 273-276.

- \& ALEXANDER, M. 1970. Cometabolism of m-chlorobenzoate by an Artbrobacter. Appl. Microbiol. 20: $254-258$. 
JAMALUDDIN, M., SUBBA RAO, P. V. \& VAIDYANATHAN, C. S. 1970. Involvement of the protocatechuate pathway in the metabolism of mandelic acid by Aspergillus niger. J. Bact. 101: 786793.

JANKE, D. \& FRITSCHE, W. 1978. Mikrobielle Dechlorinierung von Pesticiden und anderen Umweltchemikalien. Z. Allg. Mikrobiol. 18: 365-382.

- \& FRITSCHE, W. 1979. Dechlorierung von 4-Chorphenol nach extradioler Ringspaltung durch Pseudomonas putida. Z. Allg. Mikrobiol. 19: 139-141.

JOHNSTON, H, E., BRIGGS, G. G. \& ALEXANDER, M. 1972. Metabolism of 3-chlorobenzoic acid by a pseudomonad. Soil Biol. Biochem. 4: 187-190.

KARHINIEMI, A. 1977. Trials with some residual herbicides in nursery plants. Ann. Agric. Fen. 16: 37-48.

KAUFMAN, D. D. \& KEARNEY, P. C. 1976. Microbial transformations in the soil. Herbicides 2: $29-64$. Ed. L. J. Audus. 2nd Ed. London.

KAUFMAN, S. 1962. Aromatic hydroxylations. p. 129-180. Ed. O. Hayaishi. New York.

KEARNEY, P. C., KAUFMAN, D. D. \& BEALL, M. L. 1964. Enzymatic dehalogenation of 2,2-dichloropropionate. Biochem. Biophys. Res. Commun. 14: 29-33.

KLAGES, U. \& LINGENS, F. 1979. Degradation of 4-chlorobenzoic acid by a Nocardia species. FEMS Microbiol. Letters 6: 201-203.

KOKKE, R. 1970. DDT: its action and degradation in bacterial populations. Nature (London) 226: $977-$ 978.

KNACKMUSS, H-J. \& HELLWEG, M. 1978. Utilization and cooxidation of chlorinated phenols by Pseudomonas sp. B 13. Arch. Microbiol. 117: 1-7.

KREBS, K. G., HEUSSER, D. \& WIMMER, H. 1967. Z. Sprühreagenten. Dünnschichtschromatographie. Ein Laboratoriumhandbuch. p. 813-861. Heidelberg.

LONG, C. 1961. Biochemists' handbook. 1192 p. Princeton, N. J.

LUNDIN, A., RICKARDSSON, A. \& THORE, A. 1976. Continous monitoring of ATP-converting reactions by purified firefly luciferase. Anal. Biochem. 75: 611-620.

- THORE, A. \& BALTSCHEFFSKY, M. 1977. Sensitive measurement of flash induced photophosphorylation in bacterial chromatophores by firefly luciferase. FEBS Letters 79: 73-76.

MACRAE, I. C., ALEXANDER, M. \& ROVIRA, A. D. 1963. The decomposition of 4-(2,4-dichlorophenoxy)butyric acid by Flavobacterium sp. J. Gen. Microbiol. 32: 69-76.

MARKKULA, M. 1974. Sales of pesticides in Finland in 1973. Kemia-Kemi 1: 625-628.

MARSH, J. A. \& DAVIES, H. A. 1978. The effect of herbicides on respiration and transformation of nitrogen in two soils. III Lenacil, terbacil, chlorthiamid and 2,4,5-T. Weed Res. 18: 57-62.

MARTIN, H. 1971. Pesticide Manual. 495 p. 2nd Ed. British Crop Protection Council.

MASSINI, P. 1961. Movement of 2,6-dichlorobenzonitrile in soils and in plants in relation to its physical properties. Weed Res. 1: 142-149.

MEULEMANS, K. J. \& UPTON, E. T. 1966. Determination of dichlobenil and its metabolite, 2,6-dichlorobenzoic acid, in agricultural crops, fish, soil, and water. J. Assoc. Off. Agric. Chem. 49: $976-$ 981.

MILNE, G. W. A., GOLDMAN, P. \& HOLTZMAN, J. L. 1968. The metabolism of 2-fluorobenzoic acid. II Studies with ${ }^{18} \mathrm{O}_{2}$. J. Biol. Chem. 243: 5374-5376.

MISHUSTIN, E. N. 1975. Microbial associations of soil types. Microbial Ecol. 2: 97-118.

MITSEV, N. \& BOUBALOV, V. 1972. [In Bulgarian] Summary: Effect of casoran on soil and rhizosphere microflora of wheat. Georgi Dimitrov Agric. Acad. First Nat. Soil Sci. Congr. Sofia p. 233-236.

MIYAZAKI, S., SIKKA, H. C. \& LYNCH, R. S. 1975. Metabolism of dichlobenil by microorganisms in the aquatic environment. J. Agric. Fd Chem. 23: 365-368.

MORELAND, D. E., HUSSEY, G. G. \& FARMER, F. S. 1974. Comparative effects of dichlobenil and its phenolic alteration products on photo- and oxidative phosphorylation. Pestic. Biochem. Physiol. 4: 356364.

MUKULA, J. 1973. Personal communication.

NIKOLOVA, G. \& BAKALIVANOV, D. 1972. Microbiological activity and breakdown of "Casoron" herbicide in the soil. Proc. Symp. Soil Microbiol. Symp. Biol. Hung. 11: 385-389.

NIMMO, W. B. \& VERLOOP, A. 1975. Weitere Untersuchungen über den Abbau von Dichlobenil und 2,6-Dichlorbenzamid im Boden. Z. Pfl.krankh. Pfl.schutz Sonderh. 7: 147-152.

OLBERG, R. 1976. Was ist bei der Unkrautbekämpfung mit Casoron G. Prefix sowie mit Casoron Combi G und Prefix Kombi zu beachten. Allg. Forstz. 31: 246-247.

PARKER, C. 1964. Methods for the rapid bio-assay of herbicides. 7th Brit. Weed Control Conf. p. 899902. 
PATE, D. A. \& FUNDERBURK, H. H. Jr. 1966. Absorption, translocation and metabolism of ${ }^{14} \mathrm{C}$-labelled dichlobenil. Symp. Use Isotopes Weed Res. IAEA, FAO, Vienna p. 17-25.

PLIMMER, J. R. 1970. The photochemistry of halogenated herbicides. Residue Rev. 33: 47-74.

- \& HUMMER, B. E. 1968. Photochemistry of herbicides. A study of some chlorinated compounds. 155 th Meet. Amer. Chem. Soc. Abstr. A: 59.

PHAFF, H. J., MILLER, M. W. \& MRAK, E. M. 1966. The life of yeasts. p. 186. Cambridge, Mass.

RAJASEKHARAN PILLAI, V. N. 1977. Role of singlet oxygen in the environmental degradation of chlorthiamid to dichlobenil. Chemosphere 6: 777-782.

RAST, H. G., ENGELHARDT, G. \& WALLNÖFER, P. R. 1980. Degradation of aromatic compounds in actinomycete-genus Rbodococcus. FEMS Microbiol. Letters 7: 1-6.

REICH, S., SALZMANN, R. \& KAWA, M. D. 1917. Contribution á la question de l'empéchement stérique. Mem. Soc. Chim. 4. 21: 217-225.

REINICKE, W. \& KNACKMUSS, H-J. 1978. Chemical structure and biodegradability of halogenated aromatic compounds. Substituent effects on 1,2-dioxygenation of benzoic acid. Biochim. Biophys. Acta 542: $412-423$.

ROBERTS, J., STEWART, R. \& CASERIO, M. 1972. Organic chemistry. Methane to macromolecules. p. 850. Menlo Park, Calif.

RUISINGER, S., KLAGES, U. \& LINGENS, F. 1976. Abbau der 4-Chlorbenzoesäure durch eine Artbrobacter-Species. Arch. Microbiol. 110: 253-256.

RUMMUKAINEN, U. 1972. Vesakon torjunta-aineiden ja rikkakasvihävitteiden käytöstã metsänviljelyaloilla Suomessa vuosina 1969-1970. Summary: On the use of brush and weed killers on forest regeneration sites in Finland in 1969-70. Folia Forestalia 136: 1-38.

- 1974. Herbisidirakeiden männyn ja kuusen taimille aiheuttamista kuorivioituksista. Summary: On bark damages caused to Scots pine and Norway spurce plantations by granular herbicides. Folia Forestalia 194: 1-15.

SHEETS, T. J., HARRIS, C. I. \& SMITH, J. W. 1968. Persistence of dichlobenil and SD-7961 in soil. Weed Sci. 17: 245-249.

SHEPHERD, C. J. \& VILLANUEVA, J. R. 1959. The oxidation of aromatic compounds by the conidia of Aspergillus nidulans. J. Gen. Microbiol. 20: Commun. 7.

SHERMA, J. 1973. Thin-layer chromatography: Recent Advances. Analytical Methods for Pesticides and Plant Growth Regulators. Thin-Layer and Liquid Chromatography. Pesticides of International Importance. 7: 3-87. New York.

SIKKA, H., LYNCH, R. \& LINDENBERGER, M. 1974. Uptake and metabolism of dichlobenil by emersed aquatic plants. J. Agric. Fd Chem. 22: 230-234.

SILTANEN, H. \& ROSENBERG, C. 1974. Investigations on pesticide residues 1973. Publ. State Inst. Agric. Chem. (Helsinki) 9: 1-61.

- \& VALTA, A-L. 1972 a. Investigations on pesticide residues 1970, Publ. State Inst. Agric. Chem. (Helsinki) 6: 1-55.

- \& VALTA, A-L. 1972 b. Investigations on pesticide residues 1971. Publ. State Inst. Agric. Chem. (Helsinki) 7: 1-98.

SKERMAN, V. B. D. 1967. A guide to the identification of the genera of bacteria. p. 303. 2nd Ed. Baltimore.

STANIER, R. Y. \& ORNSTON, L. N. 1973. The $\beta$-ketoadipate pathway. Adv. Microbial Physiol. 9: 89151.

SVENSSON, R. 1976. Weed control in ornamental shrubs. 17th Swedish Weed Conference: H 2.

SZYBALSKI, W. \& BRYSON, V. 1952. Genetic studies of microbial cross resistance to toxic agents. I Cross resistance of Eschericbia coli to fifteen antibiotics. J. Bact. 64: 489-499.

TAYLOR, B. F., CAMPBELL, W. L. \& CHINOY, I. 1970. Anaerobic degradation of benzene nucleus by a facultative anaerobic microorganisms. J. Bact. 102: 430-437.

- , HEARN, W. L. \& PINCUS, S. 1979. Metabolism of monofluoro- and monochlorobenzoates by a denitrifying bacterium. Arch. Microbiol. 122: 301-306.

TIEDJE, J. M., DUXBURY, J. M., ALEXANDER, M. \& DAWSON, J. E. 1969. 2,4-D metabolism: Pathway of degradation of chlorocatechols by Artbrobacter sp. J. Agric. Fd Chem. 17: 1021-1061.

TIITTANEN, K. \& BLOMQVIST, H. 1976. Sales of pesticides in Finland in 1975. Kemia-Kemi 3: 424425 .

- \& BLOMQVIST, H. 1980. Sales of pesticides in Finland in 1979. Kemia-Kemi 7: 544-546.

TONKELAAR, E. M. den \& ESCH, C. J. van 1974. No-effect levels of organochlorine pesticides based on induction of microsomal liver enzymes in short-term toxicity experiments. Toxicol. 2: 371-380. 
UMBREIT, W. W., BURRIS, R. H. \& STAUFFER, J. F. 1957. Manometric technique. p. 338. Minneapolis.

VERLOOP, A. 1972. Fate of the herbicides dichlobenil in plants and soil in relation to its biological activity. Residue Rev. 43: 55-103.

- \& NIMMO, W. B. 1969. Adsorption, translocation and metabolism of dichlobenil in been seedlings. Weed Res. 9: 357-370.

— \& NIMMO, W. B. 1970. Metabolism of dichlobenil in sandy soil. Weed Res. 10: 65-70.

- \& NIMMO, W. B. 1972. Neue Erkenntnisse über das Verhalten von Dichlobenil im Boden. Z. Pfl.krankh. Pfl.schutz Sonderh. 6: 53-58.

WAKSMAN, S. A. 1967. The actinomycetes. A summary of current knowledge. p. 280. New York.

WALTER, B. 1970. Der Einfluss verschiedener Herbizide auf Struktur und Mikrobiologie des Bodens. Z. Pfl.krankh. Pfl.schutz Sonderh. 5: 29-31.

WEBSTER, J. 1970. Introduction to fungi. p. 424. Cambridge.

WHEELIS, M. L., PALLERONI, N. J. \& STANIER, R. Y. 1967. The metabolism of aromatic acids by Pseudomonas testosteroni and P. acidovorans. Arch. Mikrobiol. 59: 302-314.

WIERSMA-ROEM, W. J., VISCHER, L. W. A., FREDERIX-WOLTERS, E. M. H., HARMSEN, E. G. M., OLTHOF, P. D. A. \& WILDE, O. de 1978. Sub-acute toxicity of the herbicide dichlobenil (2,6-dichlorobenzonitrile) in rainbow trout (Salmo gairdnerii R.). Proc. Sth EWRS Int. Symp. on Aquatic Weeds. p. 261-268, Amsterdam.

WILKINSON, R. E. \& DAVIES, T. S. 1970. Pine seedling response to dichlobenil, fluometuron and pebulate. Weed Sci. 18: 292-294.

WILliams, P. A., CATTERALL, A. F. A. \& MURRAY, K. 1975. Metabolism of naphtalene, 2-methylnaphtalene, salicylate and benzoate by Pseudomonas $\mathrm{P}_{\mathrm{C}}$; regulation of tangential pathways. J. Bact. 124: 679-685.

WILliamS, S. T. \& CROSS, T. 1971. Actinomycetes. Methods in Microbiology 4: 294-334. London.

WIT, J. G. \& GENDEREN, H. von 1966. The monophenolic metabolites of the herbicide 2,6-dichlorobenzonitrile in animals as uncouplers of oxidative phosphorylation. Biochem. J. 101: 707-710.

WOODCOCK, D. 1972. Structure-activity relationships. Systemic fungicides. 34-85. Ed. R. W. Marsh, R. J. W. Byrde \& D. Woodcock. London.

Ms received December 11, 1981

\section{SELOSTUS}

\section{Mikrobien sekä herbisidien klortiamidin ja diklobeniilin keskinäiset vaikutukset}

\section{Helvi Heinonen-Tanski}

Mikrobiologian laitos, Helsingin yliopisto, 00710 Helsinki 71

Tãmä tutkimus pyrkii selvittämään herbisidien klortiamidin ja diklobeniilin mikrobiologista hajoamista, joka on erittäin puutteellisesti tunnettu.

Tyổn yhteydessã selvitettiin myōs diklobeniilin vaikutuksia muutamiin mikrobeihin tavoitteena löytāä diklobeniilille herkkiã mikrobeja, joita mahdollisesti voitaisiin kãyttää diklobeniilin määrittämiseen kemiallisen analyysin rinnalla.

Mikrobeja viljeltiin agaralustoilla, jotka sisälsivät 0-50 mg/l diklobeniiliä tai sen sukuisia aineita. Kokeissa tutkittiin 265 sädesientä (useimmat suvusta Streptomyces) sekä 41 muuta bakteeria (suvuista Aeromonas, Agrobacterium, Artbrobacter, Azotobacter, Bacillus, Cbromobacterium, Corynebacterium, Enterobacter, Escbericbia, Flavobacterium, Proteus, Pseudomonas, Rbižbium ja Xantbomonas) ja Candida-sukuinen hiiva sekä Gliocladium- ja Tricboderma-sukuihin kuuluvat sienet. 
Sädesienet osoittautuivat varsin herkiksi diklobeniilille. Peräti 61 sädesienikantaa kärsi ainakin joissain määrin kasvuliuoksen diklobeniilistä. Herkimpien sädesienien kasvu tyrehtyi jo diklobeniilipitoisuudella 1-2 mg/l. Sädesienien herkkyys diklobeniilille näyttää olevan hyvin kantakohtainen ominaisuus. Lajeista Streptomyces aureus, S. flavus ja S. bygroscopicus toinen tutkittu kanta kesti diklobeniiliä ja toinen taas oli herkkä.

Diklobeniilille hyvin herkkiä olivat S. abikoensis, S. alboniger, S. aureus, S. coelicolor ja S. virginae. Myös klortiamidi ja diklobeniilin kemiallinen sukulaisaine, 2-kloorifenyylisyanidi häiritsivät näiden sädesienien kasvua. Näiden sädesienien herkkyyttä diklobeniille voitaisiin ehkä käyttää hyväksi diklobeniilin mikrobiologisessa määritysmenetelmässä.

Sitä vastoin muut tutkitut bakteerit ja sienet sietivät sädesieniä paremmin diklobeniiliä. Ainoastaan Azotobacter agilis, Flavobacterium capsulatum sekä Enterobacter cloacae olivat jonkin verran herkkiä diklobeniilille. sillä yhden tai kahden vuorokauden ikäisissä viljelmissä diklobeniili esti osittain näiden organismien kasvua. Vanhemmissa viljelmissä ei voitu havaita mitään estovaikutuksia.

Laboratoriokokeissa diklobeniili ei kuitenkaan näyttänyt vaikuttaneen mitenkään esimerkiksi seuraviin typpeä sitoviin bakteereihin: Azotobacter chroococcum, A. indicus, A vinelandii sekä Rbizobium leguminosarum.

Kasvualustaan lisätty diklobeniili ei näyttänyt lisäävän minkään tutkitun mikro-organismin kasvua.

Klortiamidin (2,6-diklooritiobentsamidi) ja diklobeniilin (2,6-dikloorifenyylisyanidi) hajoamistutkimuksia varten eristettiin Helsingin yliopiston Viikin koetilan maasta 68 mikrobikantaa käyttäen apuna ${ }^{14}$ hiili-isotoopilla leimattua klortiamidia. Eristysalusta sisälsi vain $50 \mathrm{mg} / 1$ herbisidiä, josta osa oli radioaktiivista, mutta varsinaisena energianlähteenã oli bentsamidi. Bentsamidi valittiin energianlähteeksi siksi, ettã se muistuttaa kemiallisesti diklobeniiliä ja klortiamidia. Työssä eristettiin toisaalta niitã mikrobeja, jotka kerãsivät herbisidistă radioaktiivisuutta solujensa läheisyyteen, sekä toisaalta niitä mikrobeja, jotka alensivat ympäristönsã radioaktiivisuutta.

Useimmat tässä työssä eristetyt hajottajaorganismit olivat bakteereja. Eristetyt mikrobit kuuluivat maassa tavallisiin bakteerisukuihin kuten esimerkiksi Bacillus ja Artbrobacter. Klortiamitin ja diklobeniilin hajoaminen on useamman bakteerin yhteistyötä. Eri bakteerit pystyvät pilkkomaan molekyylin eri kohtia.

Vaikka monet eristetyt bakteerit hajottivat klortiamidia ja sen hajoamistuotetta, diklobeniiliä, hajoaminen näytti aina olevan kometabolista eli varsinaisen aineenvaihdunnan ohessa tapahtuvaa. Varsinainen energianlähde oli siis välttämätōn.

Toiset eristetyt bakteerit (Bacillus ja muutamat koryneformibakteerit) tuottivat hiilidioksidia ${ }^{14} \mathrm{C}$-leimatusta klortiamidista, mikä selitti eristyksessä havaitun kasvualustan radioaktiivisuuden alentumisen.

Toiset eristetyt Artbrobacter-sukuun kuuluvat bakteerit pystyivät hajottamaan diklobeniiliä ja eräitä sen kaltaisia aineita niin, että syntyi kloridia ja klooratut hiilivetyjohdannaiset muuttuivat vähemmän klooria sisältäviksi tai mahdollisesti kokonaan kloorittomiksi hiilivetyjohdannaisiksi, jotka voivat hajota luonnossa lähtöainetta nopeammin. Mikrobiologinen deklorinaatio tapahtui vain hapen läsnäollessa.

Deklorinoivat Artbrobacterit hajottivat myös useiden aromaattisten malliaineiden bentseenirenkaan. Ei tiedetä kuitenkaan miten deklorinaatio ja diklobeniilin aromaattisen renkaan aukeaminen liittyvät toisiinsa.

Kuvatut hajoamisreaktiot, hiilidioksidin ja kloridin vapautuminen sekã aromaattisen renkaan aukeaminen, voivat yhdessä johtaa klortimidin ja diklobeniilin täydelliseen mineralisoitumiseen. Laboratoriokokeissa 26-28 ${ }^{\circ} \mathrm{C}$ :ssa hiilidioksidin vapautuminen sivuketjusta ja deklorinaatio kestivät kuitenkin viikkoja. 